\title{
Political Jurisprudence
}

\author{
By Martin Shapmo*
}

A school of jurisprudential thought rarely emerges full blown at a single instant or immediately announces itself as something new and different in the world of legal scholarship. Bentham's Principles of Morals and Legislation, one of the most startlingly original and seminal contributions to modern legal thought, might have been greeted by one of today's omniscient and pinchminded reviewers, transplanted back to 1789 , as "a rather interesting application of the thought of several minor continental writers to English conditions." While we can now trace a whole Kantian school of legal theory, it still remains questionable whether Kant himself had a theory of law..$^{1}$ Furthermore, the contemporary world does not often find itself blessed with such commanding figures as Bentham and Kant. New intellectual movements are more often the collective work of smaller minds and the products of synthesis, recombination and shifting application of existing ideas. I believe that such a new movement is afoot in legal theory, and I propose to call it political jurisprudence.

This new movement is essentially an extension of certain elements of sociological jurisprudence and judicial realism, combined with the substantive knowledge and methodology of political science. Its foundation is the sociological jurist's premise that law must be understood not as an independent organism but an integral part of the social system. Political jurisprudence is in one sense an attempt to advance sociological jurisprudence by greater specialization. It seeks to overcome the rather nebulous and over general propositions of the earlier movement by concentrating on the specifically political aspects of law's interaction

- Dept. of Political Science, Stanford University. I wish to thank the office of the Dean of the Graduate School for a supplemental research grant made in connection with this article.

1 See Brown, Has Kant a Philosophy of Law, 71 Philosophical Rev. 33 (1962). 
with society and describing the concrete impact of legal arrangements on the distribution of power and rewards among the various elements in a given society.

From judicial realism, political jurisprudence derives a peculiar concern for the attitudes and behavior of judges and the environment of judicial decision. Indeed, many of the political jurists have devoted most of their efforts to devising a methodology that will allow them to refine and systematize the impressionistic insights of the realists by isolating and measuring the strength and direction of judicial attitudes and relating them to the actual patterns of decision.

Moreover, the new jurisprudence shares with all modern American thinking about law, the premise that judges make rather than simply discover law. ${ }^{2}$ Without this premise there could be no political jurisprudence, for one of the central concerns of politics is power and power implies choice. If the judge had no choice between alternatives, if he simply applied the rule supplied him by the tablets and reached the conclusion commanded by an inexorable legal logic, he would be of no more interest politically than the IBM machine that we could soon design to replace him. "Political" can only be linked with "jurisprudence" when it is realized that choice inheres in those phases of human endeavor that have traditionally been the object of jurisprudential study.

Finally, political jurisprudence is fundamentally indebted to political science, and its development is intimately related to the growth of political science as an independent discipline. Political jurisprudence is, among other things, an extension of the findings of other areas of political science into the realm of law and courts, an attempt to rationalize the presence of public law as a field of study within the discipline and an effort to round-out political science by somehow integrating legal and judicial facets into the total picture of political life.

Because political jurisprudence owes so many immediate intellectual debts and because it represents the extension and cross breeding of several lines of continuous intellectual endeavor, it is impossible to say exactly when the movement achieved a distinct identity or for that matter even to argue that it is a movement

2 See Cahill, Judicial Legislation (1952). 
totally distinct from other contemporaneous developments in law and the social sciences. Moreover, although the total number of political jurists is not very large and a certain amount of leader and discipleship is present, political jurisprudence has not produced any commanding intellectual figure or even set of figures, nor an orthodoxy to which all the members can subscribe. Attempting to describe and delimit it is, therefore, something like trying to analyze a literary or artistic movement. We all generally know what and whom we are talking about if the theatre of the absurd or post-abstractionist painting are mentioned. Yet it might be extremely difficult to describe exactly what common characteristics held each of these schools together. Differences, indeed direct conflicts, between various works of the same school would be mentioned, and interminable arguments would develop over whether certain marginal figures were to be included or not.

In the end, artistic movements tend to be defined in terms of tone, approach, concern for the same or similar problems, and a shared reaction to past movements rather than by a stylistic and substantive check list. More often than we are willing to admit, movements in the social sciences and philosojhy must be described in the same way. ${ }^{3}$ Political jurisprudence is such a movement, and basically I shall attempt to describe it here not by a general analysis of a purportedly complete philosophical system but by a survey of the work that has actually been undertaken, a survey that hopefully will suggest a general tone and approach as well as indicating some differences, conflicts and weaknesses.

\section{Courts as Political Agencies}

The core of political jurisprudence is a vision of courts as political agencies and judges as political actors. Any given court is thus seen as a part of the institutional structure of American government ${ }^{4}$ basically similar to such other agencies as the ICC, the House Rules Committee, the Bureau of the Budget, the city

${ }^{3}$ See e.g., Eulau, The Behavioral Persuasion in Politics (1963); Dahl, The Behavioral Approach, 55 Am. Pol. Sci. Rev. 763 (1961).

4 I shall generally treat political jurisprudence as an American movement although it is not entirely confined to this country. See e.g., Torgersen, The Role of the Supreme Court in the Norwegian Political System, Judicial Decision Making (Schubert ed. 1983). 
council of Omaha, the Forestry Service and the Strategic Air Command. Judges take their places with the commissioners, congressmen, bureaucrats, city councilmen, and technicians who make the political decisions of government. In short, the attempt is to intellectually integrate the judicial system into the matrix of government and politics in which it actually operates and to examine courts and judges as participants in the political process, rather than presenting law, with a capital $L$, as an independent area of substantive knowledge. Quite fundamentally, political jurisprudence subordinates the study of law, in the sense of a concrete and independent system of prescriptive statements, to the study of men, in this instance those men who fulfill their political functions by the creation, application and interpretation of law.

Political jurisprudence is, in a sense, the opposite of Coleridge's "willing suspension of disbelief" as a tool of understanding. The political jurist instead suspends his belief in the whole web and myth of speciality, mystery and tradition that surrounds and supports the judge. Adopting a wide-eyed, and some will grumble too open-mouthed, stance, he sees not the successor of Ulpian and Coke but only one of many government employees, operating in a bureaucratic structure, performing certain governmental services and generally engaging in the same political processes as his fellow public servants. The political jurist simply wishes to know what this fellow does in government, how he does it, why he does it and what his relations are with others in the same government structure and to the citizenry whom the government services. To be sure, in seeking to successfully answer these questions, he may have to reintroduce many of the concepts he has initially ignored if only in the form of objectively incorrect but politically relevant belief systems held by the actors he studies. Again the distinction is one of tone and approach. The political jurist begins with what any fool could plainly see if his eyes were not beclouded by centuries of legal learning, that judges and courts are an integral part of government and politics, would be meaningless and functionless outside of government and politics and are, therefore, first and foremost political actors and agencies. If all this seems obvious, it is amazing how frequently one must touch base with the obvious 
in order to avoid being caught off by the masses of writing about law and courts which are based on different and often unconsciously held premises. ${ }^{5}$

The new jurisprudence is in several ways a natural result of American experience. We are all told very early in life that the Constitution divides our national government into three great branches, and one of these is the Supreme Court. Thus the very Court that has always been preeminent in the American consciousness has always been considered preeminently an agency of government. Moreover, our mutually reenforcing preoccupations with the Supreme Court and the Constitution have made constitutional law a peculiarly important subdivision of American legal studies. And constitutional law is the most openly political of all the areas of law. The Supreme Court and its constitutional decisions have consistently played a significant and often highly controversial role in American political history. Marbury v. Madison, Dred Scott, the sick chicken, steel seizure and school desegregation cases are the very stuff of politics. While the notion of an independent judiciary may have been carried further in this country than anywhere else, the central place of the Supreme Court on the American political scene has kept us from equating independence with apoliticism or defining independence in terms of an isolated sphere of competence only peripherally related to public affairs. At least since 1937, it has become an American commonplace that the Supreme Court is either rightly or wrongly a political power holder. ${ }^{8}$

It is hardly surprising then that the Supreme Court has served as the focus for much of the new jurisprudence and indeed for much of the initial opposition to it. To begin with, the whole debate over judicial modesty versus judicial activism has been essentially an attempt to define the political role of the Court and its relations to other facets of American politics. The titles of

5 Kirchheimer, Political Justice (1961) for instance is in some ways a leading work in the new movement, and stresses the use of legal processes for political purposes. Nevertheless, lurking behind nearly every paragraph is an unspoken distinction between political justice which is a perversion of the judicial process and a non-political justice which is normal, as if somewhere at least ideally there were non-political courts.

6 See Mason, The Supreme Court: Vehicle of Revealed Truth or Power Group; 1930-1937 (1953); Mason, Myth and Reality in Supreme Court Decisions, 48 Va. L. Rev. 1385 (1962). 
some of the leading works; Congress and the Court, The People and the Court, ${ }^{8}$ and The Least Dangerous Branch, The Supreme Court at the Bar of Politics ${ }^{9}$ suggest the nature of the debate, not that all the participants share the viewpoints of political jurisprudence. The most extreme judicial self-deniers, Justice Frankfurter and Learned Hand, ${ }^{10}$ seconded by academic commentators, ${ }^{11}$ have argued that the Court should not, need not, and cannot engage in politics, that judicial review is essentially a political function, and that the Court should, therefore, cease exercising its power of review or exercise it only very rarely and under the most extreme provocation. Thus, the judicially modest are fundamentally apolitical in their jurisprudence, conceiving of courts as essentially non-political institutions and resenting Justice Marshall's ill considered institutional foray into American politics. The almost poetic tragedy of the Frankfurter-Hand-Mendelson style of judicial modesty is that, having convinced everyone that judicial reveiew was an essentially political not legal function, they have been unable to convince either a majority of the Justices or the predominant body of professional and academic opinion that the Court ought to give up review. Thus the Court continues to exercise and the legal profession to approve a function that, thanks to the work of the modest themselves, is admittedly political. In this way, the judicially modest have albeit unwilling made a considerable contribution to political jurisprudence.

This old style of judicial modesty is generally on the wane

7 Murphy, Congress and the Court (1962). At this point it might be well to explain that the footnotes in this article are dual purpose, designed both to support my statements and provide a basic bibliography of this new field. For this reason I have attempted generally to footnote a given contribution only once. Repetition of citation appears only when necessary for the support or proper illustration of my point. Many works that could and should be consulted in relation to several facets of political jurisprudence are, therefore, not noted in connection with each in order to avoid an excessively repetative bibliography. It should also be added that not all the authors and works cited would identify themselves or wish to be identified with political jurisprudence. Many have been listed which only provide data or analysis useful to political jurisprudence.

8 Black, The People and the Court (1960).

9 Bicknel, The Least Dangerous Branch, The Supreme Court at the Bar of Politics (1962).

10 Hand, The Bill of Rights (1958).

11 Wallace Mendelson has been the most prolific academic proponent of judicial modesty and has issued a very long succession of articles and reviews defending and rationalizing Justice Frankfurter's opinions. For a summary of his views see his Justices Black and Frankfurter: Conflict in the Court (1961). 
today and has been replaced by a new style of modesty reflected in the works of such commentators as Robert McCloskey and Alexander Bickel. ${ }^{12}$ In the context of our discussion here, it need only be said that the new school of modesty accepts the legitimacy of judicial review and thus of a political role for the Supreme Court and concerns itself with precisely what the Court can and cannot do considering its rather limited power. It is modest in the sense of urging the Court not to embark on tasks that are beyond its political capacity to complete or may react negatively on the Court's overall political position. Thus today the debate over judicial modesty takes place almost entirely within the framework of political jurisprudence since nearly all the parties begin from the premise that the Court, at least in the sphere of judicial review, is a political agency and that the problem of when, where and how it should exercise its review powers is essentially a political problem.

However, the above statement is necessarily a qualified one. Not every participant in the current debate over the Court is per se an active subscriber to the tenants of political jurisprudence. Professor Black for the activists for instance tends to revert to the Hamiltonian and Marshallian argument that the Constitution is law and the Supreme Court is a court of law that must therefore enforce the Constitution when it is violated. ${ }^{13}$ Such an argument is of course fundamentally apolitical, equating review with the "normal," "traditional" or routinely legal functions of courts. Judicial review becomes nothing more than a technical exercise in conflict of law jurisdiction. Professor Hynaman, in an attempt to synthesize the whole debate from the standpoint of political science, which is in effect a rather rambling defense of modesty, concludes that the Court is political in the sense of participating in government policy-making, but that a sharp contrast should be drawn between the political and the judicial process. On closer examination, however, this all boils down to the old saw that the Court is not democratic and, therefore, ought not to be political. ${ }^{14}$

12 See Shapiro, Judicial Modesty: Down With the Oldl-Up With the New?, 10 U.C.L.A.L. Rev. 533 (1963).

13 Black, op. cit. supra note 8, at 6-7.

14 Hyneman, The Court on Trial 237-47 (1963). 
Nevertheless, the debate over modesty is essentially a debate over the political role of the Court. Moreover, again thanks to the efforts of the modest themselves, particularly Frankfurter, the issue of modesty has become entangled in every substantive area of constitutional law so that constitutional scholarship as a whole has become essentially a political discipline. When every constitutional question must be considered not only on its merits, that is in terms of traditional legal analysis of the meanings of constitutional provision, statute, precedent, etc., but in terms of whether the Court is the proper governmental agency to provide the answer, then all the constitutional business of the Supreme Court involves political considerations. While much constitutional commentary is still written in the traditional mode, there has been an increasing tendency to introduce political analysis directly into the discussion of constitutional questions. This tendency is particularly marked in the area of the first amendment. ${ }^{15}$ The recent appearance of such titles as Constitutional Law in the Political Process, ${ }^{16}$ Constitutional Cases in American Government, ${ }^{17}$ Constitutional Politics ${ }^{18}$ and The Supreme Court, Its Politics, Personalities and Procedures ${ }^{19}$ is also indicative of the general tendency to integrate at least the constitutional business of the Supreme Court into the mainstream of thought about American national government. ${ }^{20}$

The principal opposition to political jurisprudence has also arisen in the area of the Supreme Court's constitutional business. The plea for neutral principles of constitutional law voiced by Professor Wechsler and his followers is in reality an attempt to substitute the traditional vision of an apolitical, non-policy making, law-discovering court for that of a court embedded in the political process and making political decisions. The Supreme

15 See Emerson, Toward a General Theory of the First Amendment, 72 Yale L.J. 877 (1963); Shapiro, Judicial Modesty, Political Reality, and Preferred Position, 47 Cornell L.Q. 175 (1962).

${ }_{16}$ Schmidhauser, Constitutional Law in the Political Process (1963).

17 Berns, Constitutional Cases in American Government (1963).

is Schubert, Constitutional Politics (1960).

10 Schmidhauser, The Supreme Court, Its Politics, Personalities and Procedures (1960).

20 See also Beth, Politics, the Constitution and the Supreme Court (1962). Three of the chapters in this book are titled "The Courts as Political Agents." In terms of the sociology of knowledge of the new movement, it is interesting to note that these works are.all texts that resulted from attempting to fit constitutional law into the mainstream of undergraduate instruction in political science. 
Court by process of legal reasoning and communion with the Constitution and the body of Anglo-American law is to divine guiding legal principles and, like all mystics, is to do so by divorcing itself from the interests and immediate problems of this everyday world. ${ }^{21}$

The concept of neutral principles has gained such great popularity precisely because it appeals to that still powerful segment of legal thought which resents the attempts of sociological jurisprudence and judicial realism to break law out of its independent sphere and place it in the context of society. ${ }^{22}$ The attempt to treat judges as essentially participants in politics, government and policy-making, ineluctably linked to other such participants, represents the extreme of integration of law into real life. The argument that there are neutral principles indwelling in the law itself and discoverable by a specifically judicial or lawyer-like mode of thought, is basically an attempt to return jurisprudence to the position of splendid isolation that it enjoyed in the heyday of analytical jurisprudence. This attempt has been largely inspired by and is a direct challenge to political jurisprudence.

Naturally enough then the rebuttal to the neutral principles concept has formed an important wing of the new jurisprudence by re-emphasizing the law and policy-making roles that are inevitably thrust on the Supreme Court. Since the Court generally deals with the "trouble case," it is typically called upon to decide precisely those questions for which neither the existing body of law nor the other agencies of government have been able to provide a solution. In short, it is asked to make social policy, and to do so it cannot depend on neutral principles but must look to its own assessment of the social and political interests involved and its own vision of the long range goals of American society. In other words, it is asked to perform the same tasks that every other political decision maker is asked to perform and to do so as a complementary and supplementary segment of the whole complex of American political institutions. Thus runs the message

21 Not all of those who desire "principled" constitutional decision are antipolitical. See Bickel, op. cit. supra note 9, at 23-28, 49-65, 236-43.

I (1960). 
of the anti-neutralists, a message that puts them squarely in the center of political jurisprudence. ${ }^{23}$

So far I have discussed only work that specifically revolves about the judicial review powers of the Supreme Court. If the political treatment of law and courts was confined to this area, it would constitute a special approach to an exceptional problem rather than a jurisprudence of relatively general applicability. But I have begun in this area largely because it serves as one of the channels through which political considerations historically flowed into the study of law not because it is the only or leading area of political jurisprudence. The principal focus of the new jurisprudence has instead been an attempt to integrate courts into the general framework of governmental institutions and the political process quite apart from a rationalization of the power of one court to do one thing, that is declare statutes unconstitutional. ${ }^{24}$ Undoubtedly the leading attempt in this area has been David Truman's The Governmental Process. ${ }^{25}$ This book presents a general theory of politics built around the notion that political activity is fundamentally interest group activity and that the process of government proceeds through the access of groups to governmental agencies and agency performance in response to group demands. Courts are treated as governmental institutions to whom different groups have varying degrees of access which they employ to enlist the judges in support of their interests. For Truman, politics is group politics and courts are firmly imbedded in the group struggle.

Probably because the first general theory of politics into which the courts were fully integrated was group theory, a considerable body of political jurisprudence using the group hypothesis has developed. ${ }^{26}$ Particular attention has been paid to

23 I have attempted to make these points at greater length and with appropriate citations in Shapiro, The Supreme Court and Constitutional Adjudication of Politics and Neutral Principles, 31 Geo. Wash. L. Rev. 587 (1963).

24 See Jacob, The Courts As Political Agencies, An Historical Analysis, 8 Tulane Studies in Political Science 9 (1963).

25 Truman, The Governmental Process (1958).

26 See Pelatson, Federal Courts in the Federal System (1955); Shapiro, supra note 15; Mavrinac, From Lochner to Brown v. Topeka: The Court and Conflicting Concepts of the Political Process, 52 Am. Pol. Sci. Rev. 641 (1958); Westin, The Supreme Court and Group Conflict: Thoughts on Seeing Burke Put Through the Mill, 52 Am. Pol. Sci. Rev. 665; Bachrach, The Supreme Court, Civil Liberties, and the Balance of Interests Doctrine, 14 Western Political Q. 391 (1961). 
groups which have been especially successful in gaining access to the courts $^{27}$ and to their methods of access or lobbying. ${ }^{28}$ Since the bar as a group has a peculiarly intimate relation to the courts, there has been an increased interest in its political role. ${ }^{29}$

However, other theories of politics may provide equally useful insights. For instance, in a critique of group theory, Elmer Schattschneider ${ }^{30}$ has argued that politics is not entirely group struggle. When one group sees itself outfought in the initial group arena, it is likely to extend the boundaries of the battlefield by broadening the issues. In other words, whichever group finds itself outnumbered in the initial alignment of groups appeals for outside re-enforcements by recasting the issue in terms that will attract the attention of groups not at first concerned. This process is likely to snowball or escalate until issues have been so broadened that general public sentiment comes into play and the issue is finally settled not by the interplay of special groups but by mass popular opinion. In this context trial court litigation might be conceived as an initial or limited arena and the appellate process as a mode of extending boundaries, or even initial litigation as an attempt to expand an issue beyond the legislative or bureaucratic sphere. ${ }^{31}$ For instance Negroes as a group, finding

$2 \pi$ See Vose, Caucasions Only: The Supreme Court, The National Association for the Advancement of Colored People and The Restrictive Covenant Cases (1959); Vose, The National Consumers League and the Brandeis Brief, 1 Midwestern J. of Political Science 267 (1957).

28 Vose, Litigation As a Form of Pressure Group Activity, 319 Annals 20 (1958); Newland, Legal Periodicals and the Supreme Court, 3 Midwestern J. of Political Science 58 (1959); Comment, Outside Influences on the Supreme Court of the United States-How Effective Are These?, 39 Can. B. Rev. 631 (1961); Jacobs, Law Writers and the Courts (1954). The Supreme Court has recently recognized that litigation is a form of political activity. N.A.A.C.P. v. Button, 83 S.Ct. 328, 336 (1963). See also, Krisloy, Constituency v. Constitutionalism: The Desegregation Issue and Tensions and Aspirations of Southern Attorney's General, 3 Midwestern J. of Political Science 75 (1959).

29 See Schmidhauser, op. cit. supra note 19, at pt. 2; Schubert, Politics and the Constitution: The Bricker Amendment During 1953, I6 J. of Politics 257 (1954); Twiss, Lawyers and the Constitution (1942). Legal professional associations present a peculiarly fruitful field for further political (pressure group) analysis. There are, of course, a large number of these associations and subassociations. Many of them are highly specialized and therefore represent particular social and economic interests. Some engage in a considerable amount of statute drafting and direct lobbying of legislatures and nearly all make public or professional pronouncements on policy questions frequently disguised as technicallegal conclusions. All have relatively high direct access to the courts and other ajudicative agencies through the pleadings of their members.

30 Schaftschneider, The Semi-Sovereign People (1961).

31 Of course even the initial trial is a broadening of arenas by introducing the government into a dispute that initially concerned only the two parties. 
that the immediate alignment of groups in the South disfavored their goals, used Supreme Court litigation to broaden the issues and attention-drawing power of the controversy and eventually overcome their local group disadvantage by enlisting national popular support.

Not necessarily dependent on group or non-group theories of politics has been a general inclination on the part of political scientists to view government in the context of decision or policymaking processes rather than formal structures. The emphasis on process is in effect an emphasis on the interaction and reciprocal influence of governmental agencies in terms of where, when and how each actually participates in decisions. Jack Peltason's Federal Courts in the Federal System ${ }^{32}$ and Victor Rosenblum's Law As a Political Instrument ${ }^{33}$ were pioneering efforts to fit courts into this policy-making process framework by showing how they interact with other governmental agencies at all levels. A recent and outstanding text designed to introduce beginning law students to their field suggests its approach in its title, The Legal Process, An Introduction to Decision-Making by Judicial, Legislative, Executive and Administrative Agencies ${ }^{34}$ and sets both courts and law firmly within the sphere of public policy-making. Robert Dahl's article "Decision-Making in a Democracy: The Supreme Court as a National Policy-Maker" is an attempt to generally assess the relations of the Supreme Court to other members of "the dominant national alliance," and there have been several attempts to describe the Court's policy-making role and relation to other agencies in specific areas of its jurisdiction. ${ }^{35}$

The case study technique of examining court decisions popu-

32 Peltason, op. cit. supra note 26.

33 Rosenblum, Law as a Political Instrument (1955). See also Miller, PolicyMaking in a Democracy: The Role of the United States Supreme Court, $6 \mathrm{~J}$. Pub. I. 275 (1957); Schubert, Policy Without Law: An Extension of the Certiorari Game, 14 Stan. L. Rev. 284 (1962); Sutherland, Judicial Reticence and Public Policy, 1958 Juridical Rev. 1; Nagel, Political Parties and Judicial Review in American History, 11 J. Pub. L. 328 (1962).

34 Auerbach, Garrison, Hurst, and Mermin, The Legal Process, An Introduction to Decision-Making by Judicial, Legislative, Executive and Administrative Agencies (1961).

35 Dahl's article appears in 6 J. Pub. L. 279 (1957). See also Shapiro, The Warren Court and the Federal Tax Policy, 36 So. Cal. L. Rev. 208 (1962); Barker, The Supreme Court As Policy Maker: The Tidelands Oil Controversy, 24 J. of Politics, 350 (1962); Ulmer, Judicial Review As Political Behavior: A Temporary Check on Congress, 4 Ad. Science Q. 426 (1960). 
larized by Alan Westin ${ }^{36}$ is also part of the movement toward examining what courts do in the total political setting of their decisions. It is to be sure a bit confusing to talk about case studies of cases. But the case study technique in the social sciences refers to a research design that focuses on a given decision, or set of related decisions, and then develops in the greatest possible detail all the institutional and individual attitudes and behavior that led up to and out of the decision. Such depth studies are designed to validate or suggest the broader hypotheses which it is the goal of the social sciences to formulate. When applied to law, this technique can be used to focus on a given court decision and develop the political matrix in which it occurs showing that the decision is not an independent or isolated event but an integral part of a political process in which many agencies interact with one another.

While most of the efforts to fit courts into the general pattern of politics have so far occurred at the level of American national government, several recent studies have dealt with the political role of state and foreign courts. ${ }^{37}$ Relations between the U.S. Supreme Court, the lower federal courts and the state courts, which have traditionally been handled in the conventional legal categories of jurisdiction, have also begun to receive some attention in more realistic political terms. ${ }^{38}$ The most suggestive approach proposes a view of lower courts as essentially bureaucratic structures suggesting that the problems of the highest appelate courts may be basically similar to those of other political leaders vis à vis their bureaucratic subordinates. ${ }^{39}$

${ }^{36}$ See Westin, The Anatomy of a Constitutional Case (1958); Pritchett and Westin; The Third Branch of Government, Eight Cases in Constitutional Politics (1963); Westin, Bookies and "Bugs" in California: Judicial Control of Police Practices, The Uses of Power (1962). Another case in the latter work, Hacker, Pressure Politics in Pennsylvania: The Truckers vs. The Railroads, provides a peculiarly good illustration of the entanglement of the courts in policy-making and pressure group politics.

$37 \mathrm{Jacob}$ and Vines, The Role of the Judiciary in American State Politics, Judicial Decision-Making (Schubert ed. 1963); Vines, Political Functions of $a$ State Supreme Court, 8 Tulane Studies in Political Science 51 (1962); Jacob, Politics and Criminal Prosecution in New Orleans, Id. at 77; Schubert, Quantitative Analysis of Judicial Behavior $129-142$ (1959); Ulmer, The Political Party Variable in the Michigan Supreme Court, 11 J. Pub. L. 352 (1962). See also note 4 supra. (1961).

38 See e.g., Murphy and Pritchett, Courts, Judges and Politics 584-617

${ }_{39}$ Murphy, Chief Justice Taft and the Lower Court Bureaucracy: A Study (Continued on next page) 


\section{The Attitudes of Judges and Courts as Small Groups}

So far I have been describing what might be called the institutional wing of the new jurisprudence which attempts to integrate courts as political institutions and judges as political actors into the general pattern of American political institutions. In a fundamental sense it is this wing of the new jurisprudence that is the most radical, for it tends to extend the teachings of sociological jurisprudence to their logical extreme and break down any remaining barriers between law and politics. The term "social engineer"-so appealingly dispassionate and scientificreplaced the black robe with the white laboratory coat. Political jurisprudence rends the euphemism and calls a policy-maker a politician.

Strangely enough, however, it is not this but another wing of political jurisprudence that raises the most hackles. The nature of this wing might be suggested by Gutman scales, bloc analysis, Shapeley-Shubik indices, game theory, etc., in short by charts and graphs, $X$ 's and $Y$ 's and symbolic equations. Yet in describing these intellectual phenomena it would be misleading to speak of a quantitative school of political jurists or to treat the quantifiers as a separate group. First of all quantification or statistical analysis is not an independent approach to any body of subject matter. At its best it suggests neither what questions are significant, what data is relevant, nor what ought to be done with the answers. Quantification is simply a tool and in political jurisprudence it is usually a tool for expressing more clearly and systematically observations that have been or might be made by other methods. Quantification may be used without any particular intent to contribute to an essentially political analysis of courts as it is in the Harvard Law Review's annual statistical description of the previous term's work of the Supreme Court. Or statistics may be used as one mode for carrying on the essentially institutional analysis we have already described. For instance, one might prepare statistical summaries of the incidence of Supreme Court reversals of acts of Congress or of state courts of appeal in order to partially determine how much power the

(Footnote continued from preceding page)

in Judicial Administration, $24 \mathrm{~J}$. of Politics 453 (1962); Lower Court Checks on Supreme Court Power, 53 Am. Pol. Sci. Rev. 1017 (1959). 
Supreme Court has wielded over other agencies at what times on what issues. ${ }^{40}$ Thus several quantitative studies have already appeared in earlier footnotes supporting my description of the policy-making approach to courts. Or quantitative devices might be used, as we shall see shortly, in attempts to analyse sub-institutional problems such as the attitudes of individual judges.

Moreover, many of the treatments that at first glance seem somehow mathematical are really nothing more than logical propositions expressed in the language of equations or other symbolic systems and thus are not actually quantitative or only incidentally so. And, of course, such modes of expression too can be used in support of all sorts of approaches to the Court. For instance Schubert's article "Policy Without Law: An Extension of the Certiorari Game"41 uses the formal language of game theory to indicate, among other things, that the Supreme Court's certiorari practice may be determined not by formal rules of jurisdiction but by the policy preferenced of the Justices. Since the thrust of Schubert's piece is that certiorari is one mode of Court participation in the policy-making process, it makes more sense to list it as I have done in the context of the policy-making approach to the Court than isolate it in a methodological ghetto called "game theory approaches."

Indeed, the attempt to lump all "counters" together is really a function of the basic distaste to be found among many students of law for any other than their own traditional language. It is rather as if English and American lawyers accustomed to writing in English, and impatient with irregular verbs, lumped all the legal studies of French writers under the category French jurisprudence. Once the lumping is done, it is much easier to make blanket statements about the absurdity of writing about law in French than it is to analyse in detail whether any of the French writers have had anything useful to say in their peculiar language. I shall have more to say of this later. For the moment it is enough to avoid categories that shed more heat than light.

40 See Ulmer, An Empirical Analysis of Selected Aspects of Law Making of the United States Supreme Court, 8 J. Pub. L. 414 (1959). My colleague Robert Horn is currently at work on a study of the relations between the U.S. and the state supreme courts that will be supported by extended statistical evidence on reversals and upholdings. See also Blaustein and Field, "Overruling" Opinions in the Supreme Court, 57 Mich. L. Rev. 151 (1938).

${ }_{41}$ Schubert, supra note 33 . 
But for this heat and light problem I would be tempted to call this second wing of political jurisprudence the behavioral approach. ${ }^{42}$ Those of my readers who are political scientists will know what rocks and shoals lie along that course. Suffice it to say that political scientists have for some years been engaged in a great debate between behaviorists and non- or anti-behaviorists that is complicated by the fact that it is difficult to define behaviorism precisely. ${ }^{43}$ Much of the writing that I shall presently describe has been produced by self-acknowledged behaviorists and so has become part of the debate. Due to a kind of cultural lag in the area of public law which I do not have the courage to try to explicate here, the struggle broke into a white heat in that field after a modus vivendi had been reached in most other areas of political science. Because I believe this verbal battle to be ephemeral, I do not use the label "behaviorist" here in order to avoid encumbering my description of a new jurisprudence with the categories of an absolescent debate.

There is another reason as well. While it is undoubtedly true that in fact much of the new jurisprudence is a result of the somewhat delayed incursion of behaviorism into the study of law, it is inconvenient to emphasis behaviorism as such excessively. To do so would tend to obscure the fact that the phase of the new jurisprudence I am about to describe is a logical development of judicial realism and that the basic continuity between realism and political jurisprudence is very great. What others might choose to call the behavioral wing of the new jurisprudence is basically an attempt to systematize and confirm the insights of judicial realism through techniques borrowed from the social sciences. While it is perfectly proper to stress the methodological continuity of the psychological and sociological study of judges with the psychological and sociological study of other people and thus speak of "judicial behavior" as a branch of a broader behaviorism, I choose instead to emphasize the jurisprudential con-

42 See Schubert, Bibliographical Essay, Behavioral Research in Public Law, which contains most of the items noted in this article, but treates them from the standpoint of the behavioral sciences. See also his introduction to Judicial Decision-Making, op. cit. supra note 4 entitled From Public Law to Judicial Behavior. Becker, An Inquiry Into a School of Thought in the Judicial Behavior Movement, 7 Midwest J. of Political Science 254 (1963) provides some critical comments on the behaviorialist from the point of view of someone deeply committed to political jurisprudence.

43 See Dahl, supra note 3. 
tinuity of new methods of assessing judicial attitudes with more traditional attempts to gain insight into the judge's mental processes.

After all, how a judge thinks-how he arrives at the conclusion he does-has always been a central concern of jurisprudence. The logical analysis of analytical jurisprudence was basically designed to show what mental processes a judge went through in order to reach his decision. For all the seeming anachronism of such phrases as stare decisis and ratio decedandi, they were and are great surgical tools designed to dissect the anatomy of judicial decision and show us just how each thought of the judge related to every other until the final system was complete and the judgment rendered. Analytical jurisprudence rested on the assumption and assertion that judges thought logically. When later jurisprudential movements destroyed this concept of independent legal rationality, they took upon themselves the task of discovering how judges did in fact think. Carodozo's Nature of the Judicial Process shows how difficult that task became once legal logic had lost its sovereign role and illustrates what inexact and impressionistic substitutes postanalytical jurisprudence provided. The rule skepticism of realism added the final touches. Hunch and sense of injustice theories ${ }^{44}$ were final confessions that, cut adrift from traditional legal logic, and confined to traditional tools of analysis-largely introspection -jurists could do little more than hang a tag on determinants of decision which they knew were there somewhere but could not describe or analyse.

One of the tasks of political jurisprudence has been, through the use of new tools, to reopen the examination of judicial thought processes. Such an attempt follows directly from the premise that judges are political actors. For students of politics have long been widely concerned with the relation of socio-economic background and psychological make-up to political attitudes and the relation of attitudes to political action. ${ }^{45}$ Put another way, if judges are viewed as policy-makers, then it is natural to ask

44 See Frank, Law and the Modern Mind 101-104 (1930); Cahn, The Moral Decision (1955).

45 See Key, Public Opinion and American Democracy (1961); Lasswell, Psychopathology and Politics (1930). 
of them as one asks of other policy-makers, how do their individual value preferences effect their policy decisions. The traditional concern with judicial thought processes meshes nicely with the modern interest in the motivational aspects of political action.

In order to determine the effects of individual attitudes on judicial decisions, one must first identify the attitudes, and so far the bulk of attitudinal research has been aimed in this direction. Basically the effort has been to derive judicial attitudes from judges' voting behavior by the mutually supporting techniques of scalogram and bloc analysis. Leaving aside the details of technique which are clearly and adequately described elsewhere ${ }^{46}$ the logic of these studies is simple and straightforward. A scalogram collects a set of cases all of which invoke a common set of social, economic or political problems-say the civil liberties cases. If Justice Douglas always votes for the individual asserting violation of his liberties, regardless of the legal and factual circumstances, he probably has very strong pro-civil liberties attitudes. If Justice Warren votes for the individual most of the time but not quite as often as Douglas then he probably has strong pro-civil rights attitudes but not so strong as Douglas. ${ }^{47}$ In bloc analysis the voting patterns of multi-judge courts are analyzed and if it is found that Black, Warren, Douglas and Brennan for instance vote together most of the time on a certain variety of case, it seems probable that they share some common attitude toward the policy issue raised in that sort of case. By determining what blocs form on what kinds of issues, inferences can be made about the shape and distribution of attitudes among the various Justices. So far the description of attitudes has been rather rough, beginning with Herman Pritchett's pioneering efforts at group analysis which came down to little more than left

${ }^{40}$ Schubert, The Study of Judicial Decision Making As an Aspect of Political Behavior, 52 Am. Pol. Sci. Rev. 1007 (1958); Ulmer, Scaling Judicial Cases: A Methodological Note, 4 American Behavioral Scientist 31 (1961). Those readers unfamiliar with scaling and group analysis should probably not proceed any further until they have consulted at least one of these pieces or one of those mentioned in note 49 infra. For convenience I have reproduced in an appendix one scale and one bloc diagram so that the format will at least be familiar.

47 Of course basic to scale analysis is the assumption that if a true scale can be constructed, then the scaled material is ordered along a single attitudinal dimension. 
and right categories. ${ }^{48}$ More recently attitude clusters defined in terms of libertarianism and economic liberalism have been identified. ${ }^{49}$

There are several other methods of defining the political attitudes of judges other than extrapolating them from their voting behavior. Obviously biographical study is one of these, and one by the way that is not statistical or quantitative or behavioral in any peculiar sense but nevertheless is an integral part of the attitudinal approach. Judicial biography has a long and honored tradition in the United States, but much of it results from the notion that some of the judges were great men and the lives of great men should be chronicled. Judicial biography enters the main stream of political jurisprudence when it becomes a conscious attempt to discover what the values, philosophies and ideologies of judges were in order to discover how those views affected the way each judge thought about and decided cases. ${ }^{50}$

John Schmidhauser has suggested collective biography as a supplement to individual biography in this area. ${ }^{51}$ Data on the socio-economic backgrounds, education, mode of recruitment into

48 Pritchett, The Roosevelt Court, A Study in Judicial Politics and Values, 1937-1947 (1948); Pritchett, Civil Liberties and the Vinson Court (1954). These two works are pioneering efforts in the political analysis of the Supreme Court. For another left-right analysis see Jacobs, The Warren Court After Three Years, 9 Western Political Q. 937 (1956). See also Christensen, Bloc Voting on the Supreme Court (unpublished honors thesis, Harvard College).

49 Ulmer, Supreme Court Behavior and Civil Rights, 13 Western Political Q. 288 (1960); Spaeth, Warren Court Attitudes Toward Business: The " $B$ " Scale, Judicial Decision Making (Schubert ed. 1963); An Analysis of Judicial Attitudes in the Labor Relatoins Decisions of the Warren Court, $25 \mathrm{~J}$. of Politics 290 (1963). See also Ulmer, The Analysis of Behavior Patterns on the United States Supreme Court, 22 J. of Politics 629 (1960); Tannenhaus, Supreme Court Attitudes Toward Regulatory Agencies, 14 Vand. L. Rev. 473 (1961). Since Tannenhaus uses techniques normally employed in voting analysis as opposed to scalograms and arrives at conclusions that partially contradict those of the scalers, his article deserves particular attention. The conflict in part occurs because the votes of a Justice which seem inconsistent when summated, in the sense that he has sometimes voted for and sometimes against a given interest or agency, may seem consistent when scaled, in the sense that all his no's may appear on one end of the scale and all his yeses on the other. See note 82 infra. Schubert has attempted to combine scale, bloc and factor analysis to present a single overall picture of the Supreme Court. See his A Psychometric Model of the Supreme Court, 5 American Behavioral Scientist 14 (1961); Schubert, The 1960 Term: A Psychological Analysis, 56 Am. Pol. Sci. Rev. 90 (1962).

50 See e.g., Tresolini, Justice and the Supreme Court (1963). A good brief summary and bibliography of the current state of judicial biography appears in Pannam, Judicial Biography-A Preliminary Obstacle, 4 U. Queensland L.J. 57 (1961).

51 Schmidhauser, The Justices of the Supreme Court: A Collective Portrait, 3 Midwest J. of Politics 1 (1959). See also Edwin, The Judges of the Supreme Court, 1789-1937 (1938). 
judgeships, previous occupation, partly affiliation, etc. of judges can be gathered, and, using this data, inferences can be made about the content and distribution of judicial attitudes. Where correspondences can be found between background and decisional behavior, it may be inferred that attitudes corresponding to that background have actually played a part in reaching the decisions. ${ }^{52}$ Here again, statistics rears its head, but as a facilitator of mass biography rather than a peculiar or mysterious form of discourse set apart from other streams of study.

Parallel to this attitudinal research, and using much of the same data and techniques, is a rather specialized wing of political jurisprudence that deals with the internal relations of multijudge courts. Once judges are viewed as actors and decisionmakers rather than law-finders, the mutual influence of members of a judicial panel on one another takes on considerable interest. One approach is to treat the nine Justices of the Supreme Court as a small group in the context of what we know of the sociology of small groups. ${ }^{53}$ The extent of leadership exercised by the Chief Justice, which has always been of concern to students of the Court, can be studied in terms of political leadership. ${ }^{54}$ While most of the bloc analysis has been aimed at identifying attitudes, similar analysis can also be used to chart the group politics of a court itself or the influence over final outcome that "swing" justices may have..$^{55}$

52 See Schmidhauser, Stare Decisis, Dissent and the Background of the Justices of the Supreme Court, 14 U. Toronto L.J. 194 (1962) and Judicial Behavior and the Sectional Crisis of 1837-1860, 23 J. of Politics 615 (1961); Nagel, Testing Relations Between Judicial Characteristics and Judicial Decision-Making, 15 Western Political Q. 425 (1962), Judicial Backgrounds and Criminal Cases, 53 J. Crim. L., C. \& P.S. 333 (1962), Ethnic Affiliations and Judicial Propensities, 24 J. of Politics 92 (1962), Unequal Party Representation on the State Supreme Courts, $45 \mathrm{~J}$. Am. Jud. Soc'y 62 (1961), Political Party Affiliation and Judges Decisions, $55 \mathrm{Am}$. Pol. Sci. Rev. 843 (1961); Ulmer, The Political Party Variable in the Michigan Supreme Court, 11 J. Pub. L. 352 (1962), Public Office in the Social Background of Supreme Court Justices, 21 Amer. J. Economics \& Sociology 57 (1962); Goff, Old Age and the Supreme Court, 4 Am. J. Legal Hist. 95 (1960).

53 Snyder, The Supreme Court as a Small Group, 36 Social Forces 232 (1958); Ulmer, Homeostatic Tendencies in the United States Supreme Court, Introductory Readings in Political Behavior (Ulmer ed. 1961). See also Newland, Personal Assistants to Supreme Court Justices: The Law Clerks, 40 Ore. L. Rev. 299 (1961).

54 Murphy, Marshalling the Court: Leadership, Bargaining and the Judicial Process, 29 U. Chi. L. Rev. 640 (1962); Danelski, The Influence of the Chief Justice in the Decisioned Process, Courts, Judges and Politics (Murphy and Pritchett eds. 1962). See also Ulmer, Leadership in the Michigan Supreme Court, Judicial Decision Making (Schubert ed. 1963).

55 See Pritchett, supra note 48. 
Finally there is at least potentially a wing of political jurisprudence that may be labeled crude behaviorism. It is also closely linked to judicial realism and ultimately to Holmes' overstated definition of law as a prediction of what courts will do. If, for instance, we can discover that Justice $X$ has over a long period in the past consistently voted for labor and against management, we have learned something useful quite aside from whether we can speak meaningfully of pro-labor attitudes. While perhaps we cannot scientifically predict that Judge $X$ will continue to vote for labor in all future cases unless we can explain why he has done so in the past, we can predict at the level of prudence. Past patterns of judicial decisions, even when we can find no explanation for them, and therefore, must treat them as below the level of theoretical significance, may provide us with useful tools for rough and ready prediction. Whether a given group is more likely to get what it wants out of a given court or judge or had better try a different court, or some other agency of government entirely, is a significant political question to which an immediate, imperfect answer is often more desirable than a long deferred, perfect one.

It might be well to say something more at this point about the flnurry of activity in the area of prediction. First of all, efforts to predict by computer and other statistical means ${ }^{56}$ are for the most part not an integral part of political jurisprudence but rather a revival of analytical jurisprudence. Basically they are attempts to analyse past precedents and then project whatever consistencies are discovered into the future on the assumption that courts will decide tomorrow as they did yesterday, i.e., follow precedent. That has always been a basic part of the lawyer's trade and more specifically of the analytical tradition.

The basically analytical rather than political character of predictive approaches has been partially obscured by the fact that some of the most interesting and controversial prediction has been done by a political scientist, Fred Kort, in a political science setting. ${ }^{57}$ I suspect more people have read the title than

56 For a general description of the computer problem see Brown, Electronic Brains and the Legal Mind: Computing the Data Computer's Collision With Law, 71 Yale L.J. 239 (1961).

57 Kort, Predicting Supreme Court Decisions Mathematically: A Quantitative Analysis of the "Right to Counsel" Cases, 51 Am. Pol. Sci. Rev. 1 (I957); Kort, 
the article. Kort deals only with a very limited area of appellate court work. Under the fair trial and certain similar rules, an appellate court announces that it will declare no particular circumstance or action illegal per se but will weigh all the relevant circumstances and if a sufficient number of circumstances appear to a sufficient degree, it will find a violation of its rule. In effect the appellate court constitutes itself the trier of facts determining whether a given set of facts taken as a whole constitutes unfairness, negligence, etc. A court rarely specifies in advance all the circumstances or tells us how much weight on any one or more will be sufficient to constitute violation. Subsequent case by case adjudication provides the specifics that the court initially omitted. Since the judges are rarely willing to provide a running summary, students of law must analyse the precedents and present a systematic statement of precisely what fact situations will constitute violation. Kort attempts this rather traditional analytical task by some rather untraditional methods, but his "prediction" is basically a systematic statement of what combinations of circumstances the appellate court has considered a violation and what combinations it has not. One may if one wishes make the assumption that so long as the rule survives, the judges will use the same criteria they have used in the past in weighing up the circumstances, and thus predict future decisions. Kort as a matter of fact uses prediction only to test his analytical exercise. If he has properly enunciated the criteria that the judges have used but thoughtlessly refused to enunciate themselves (or used with too little self-consciousness to enunciate), then his application of his criteria to any given set of facts should yield the same decisional result as does the court's own analysis. Thus for his purposes he might just as well predict cases that have already been decided, and that is precisely what he does. It should be emphasized that Kort is not analysing or predicting how courts will decide new or open questions of law but only what combinations of circumstances will cause them to find that a violation of a very special variety of pre-established legal rule has in fact occurred.

\section{(Footnote continued from preceding page)}

Content Analysis of Judicial Opinions and Rules of Law, Judicial Decision Making (Schubert ed. 1963). See also Nagel, Using Simple Calculations to Predict Judicial Decisions, 4 Am. Behavioral Scientist 24 (1960); Ulmer, Supreme Court Behavior in Racial Exclusion Cases; 1935-1960, 56 Am. Pol. Sci. Rev. 325 (1962). 
In general prediction is incidental to jurisprudential inquiry -a mode of proof for hypotheses about the way the judicial process works. It can thus on occasion be found in conjunction with political jurisprudence as with any other kind. Attitudinal or psychometric descriptions of a court might be partially tested by their ability to predict decisional outcomes. ${ }^{58}$ The attempt to discover uniformities or formulate generalities of a high level of applicability is one of the aims of social science. Prediction is intimately related to this aim. To the extent that political jurisprudence is a social science, it will, therefore, be involved in prediction and welcome verification of its hypotheses by the predictive method. But prediction is neither a peculiar, sufficient or necessary characteristic of political jurisprudence.

Leaving problems of prediction aside, attitudinal analysis will often yield the simple information that a given judge has in all past cases voted for a particular policy or group. When we find that Justice $X$ has consistently voted pro-labor, that is a political fact with political impact regardless of his intentions. The analysis of the extent to which a court's decisions favor or disfavor certain interests and other agencies of government, wholly aside from inferences as to whether intention to do so motivated the decisions, aids in the assessment of that court's impact on the political process and its relation to other parts of government. Since one of the principal tasks of political jurisprudence is to discover the functions and powers of courts vis à vis other political agencies, gross calculations of the effects of decisions are relevant to political jurisprudence as a whole if not directly to the problem of judicial attitudes. Thus many of the calculations that leave us undecided as to the motivations of say Justice Frankfurther are quite helpful in assessing the sum of the political impact of his decisions. Surely the results of a political decisionmakers choices, particularly when they favor a given policy or policy-maker, are just as or more important than his reasons for making them.

\section{Criticisms and Proposals}

There has already been and is yet likely to be a great deal of criticism of political jurisprudence. I shall attempt to sketch some

58 The ability to predict is not, however, a necessary or sufficient test in this area. See Fisher, The Mathematical Analysis of Supreme Court Decisions: The Use and Abuse of Quantitative Methods, $52 \mathrm{Am}$. Pol. Sci. Rev. 321 (1958). 
of these criticisms and suggest replies. Because political jurisprudence is a relatively new movement, much of the criticism is directed to its incompleteness. Therefore, many of my replies will in fact be proposals for future research.

Probably the principal complaint about political jurisprudence is that it obscures the uniqueness of law and legal institutions. In constantly repeating that courts are political agencies and judges political actors, and dealing with courts and judges as an integral part of government, political jurisprudence does tend to emphasize the similarities between courts and judges and other political institutions and politicians. But if all this seems to add up to the statement that judges are just a bunch of politicians, then the mistake is in the eye of the beholder and in the unfavorable connotation frequently attached to the words politics and politician. The study of things political is, to be sure, partially aimed at exposing similarities between various political actors and institutions, but surely it is also aimed at discovering their difference. The State Department, the Cook County democratic machine, the Vatican, the ICC and the Supreme Court are all political agencies and share certain common features. But in saying this, I suppose no one believes that I am saying that the Secretary of State, Take Arvey, the Pope, the chairman of the ICC and Chief Justice Warren are or should be exactly the same kind of men, thinking the same kind of thoughts and doing exactly the same kinds of things. If I say that Al Capone and F.D.R. were both politicians, I am not saying that the President was just a gangster.

It is true that initially political jurisprudence has probably overemphasized the commonality between courts and other agencies of government. But it is so difficult to eradicate the fundamentally apolitical outlook of both lawyers and laymen, who constantly and almost instinctively backslide into the cliches of the black robed myth, ${ }^{50}$ that it was inevitable and necessary that the point be made by over-emphasis. Now that the essentially political role of courts is relatively firmly established, it should be possible for political jurisprudence to turn more of its attention to analyses of the differences in political role between courts and

59 See e.g., Williamson, Political Process or Judicial Process: The Bill of Rights and the Framers of the Constitution, 23 J. of Politics 199 (1961). 
other agencies. The proliferation and complexity of modern government is largely based on the differentiation of function among agencies. If courts and judges were not performing a political function somewhat different from other political agencies and personnel and bringing relatively unique qualities into the political arena, they would not be nearly as politically successful as they are. Political jurisprudence in the future will seek to explore the special qualities of courts and in the light of those qualities determine what particular governmental chores suit the courts better than their fellow agencies. ${ }^{60}$

Political jurisprudence is also open to the criticism that it has focused almost entirely on the Supreme Court and constitutional law. By picking the admittedly most political court and most political body of law as the basis for creating a model, it might be seriously distorting its description of the relation between politics and law. Again there may have been an initial sin of overemphasis to make the point. It is easier to get Americans to grasp a political or governmental context for the Supreme Court than for other courts. But that does not mean that in reality other courts are less political. Surely the lower courts collectively make a great deal more law than the Supreme Court and some individual courts make considerably more policy in particular areas than do the courts above them. The fifth circuit for instance is much more influential in the development of oil and gas policy than is the Supreme Court. Moreover, distinctions between constitutional, public and private law are only matters of degree. The Supreme Court's anti-trust jurisdiction involves broader ranging political considerations than does its fourth amendment business and areas like labor law exhibit an inextricable tangle of constitutional principle and statutory interpretation. No elaborate argument is required to prove that such eminently private law areas as contract and tort are vehicles for public policy and for the regulation of individuals by government in the public interest. ${ }^{61}$ The government is the third party to every private suit and is so in the very form of the law and the judge who administers it.

60 See Hyneman, op. cit. supra note 14; Bicknel, op. cit. supra note 9; Shapiro, op. cit. supra note 35 , at 225-227. (1959-60). 
Nevertheless, there is no doubt that political jurisprudence has concentrated too heavily in the past on Court and Constitution. ${ }^{62}$ Political science as a discipline passed through a long period of excessive concentration on national government largely because the plethora of divergent state and local institutions presented an intimadating prospect for study. Eventually, however, there was a great explosion into the field of state and local government. We are, I hope, on the verge of a similar explosion in jurisprudence. ${ }^{63}$ Part of that explosion will be in the form of study of discrete state supreme and other courts with the same thoroughness as the U.S. Supreme Court has been studied. As yet we have almost no descriptive data for instance on the operation of intermediate appellate courts. ${ }^{64}$

Probably the most pressing of all the tasks of political jurisprudence is the development of a systematic description and analysis of the relation between lower and higher appellate courts in terms of power, influence and differentiation of function. Let me give just one example to suggest the range of problems. Certain federal circuits build up special expertise in certain fields of public policy, for instance the fifth circuit's oil and gas jurisdiction just mentioned. The admiralty jurisdiction of the second circuit also comes to mind. We know that in other parts of government specialization and expertise can be powerful forces fostering independent policy views and excessive resistance to supervision and coordination on the part of subordinate agencies. The same specialization often provides the political tools for fulfilling those policy views and making good the resistance. To what extent does specialization and the resultant expertise of certain circuit courts cause them to adopt different views than their more generalized counterparts and resist or seize policy leadership from the Supreme Court in those areas that especially interest them? To what extent have litigants who have a choice

62 But see Spaeth, supra note 49 .

63 See the work of Jacob and Vines collected in 8 Tulane Studies in Political Science (1962) and their The Role of the Judiciary in American State Politics, Judicial Decision Making (Schubert ed. 1963).

64 For a long time Judge Magruder's informative and witty piece, The Trials and Tribulations of an Intermediate Appellate Court, 44 Cornell L. Q. 1 (1958), stood almost alone. But now see Norvell, Chadwick and Donovan, The Work of the Texas Courts of Civil Appeals 1951 to 1958, 38 Texas L. Rev. 725 (1960); Note, The Second Circuit: Federal Judicial Administration in Microcosm, 63 Colum. L. Rev. 874 (1963), Even less has been done on the federal district courts, but see Peltson, Fifty Eight Lonely Men (1961). 
of circuits taken advantage of these phenomena to achieve the ends they desire? What methods, if any, have the highest appellate courts used to achieve supervision over and coordination of such specialized lower appellate courts?

In spite of the great prominence of appellate courts in the American judicial structure, generally speaking we as yet know very little about the fundamental problems of interagency relations and coordination posed by our appellate court structure. I have already said that the most promising approach seems to be that of Walter Murphy who views the lower courts as a form of bureauacracy. However, up to this point little has been done to relate the tools that administrative, organizational and communications theorists have developed for the study of other hierarchically organized bureaucracies to the study of courts. ${ }^{65}$ This kind of endeavor should become a core area of political jurisprudence in the future.

Finally, political jurisprudence in spite of its close relation to judicial realism has done very little with trial courts, largely I think, because their role in the policy-making process is least evident and they are most difficult to study. However, in recent years political scientists have considerably developed the technique of direct observation and interrogation of local units of government. ${ }^{68}$ We should now begin to send scholars into our local courts to systematically observe their behavior over fairly long periods of time, interview litigants, counsel and subordinate court officers and where possible interrogate the trial judges themselves. We could then begin to build up the body of empirical data necessary to proceed beyond the very vivid but quite haphazard and impressionistic studies of Judge Frank. ${ }^{67}$

65 The literature of administration and bureaucracy is very large. Pffiffner and Prestus, Public Administration (1960); Pffiffner and Sherwood, Administrative Organization (1961); Blau and Scot, Formal Organization: A Comparative Approach (1962), are recent survey works that note most of the important contributions. Such journals as the Public Administration Review and The Administrative Science Quarterly serve as central clearing houses for new ideas in this area. Some spade work on the relations between various levels and groups of courts has been done. See Snyder, Uncertainty and the Supreme Court's Decisions, 65 American J. Sociology 241 (1959); Nagel, Sociometric Relations Among American Courts, 43 Southwestern Social Science 136 (1962). press).

66 See Dahl, Who Governs (1961); Wolfinger, The Politics of Progress (in

${ }_{67}$ Frank, Courts on Trial (1949). See Somit, Tanenhaus, Wilke, Aspects of Judicial Sentencing Behavior, 21 U. Pitt. L. Rev. 613 (1960). Curiously enough,

(Continued on next page) 
Moreover, we know little of the relative power and function of local courts within the policy-making processes of local government. More effort must be made to exploit the current boom in urban studies in the United States to yield information on this point in addition to the routine statistics on case load and delay that are now available. In this respect a crucial series of questions about any governmental agency is: how well does it do the jobs assigned it, what services can it best perform, and is it acquring or loosing functions? These are key political questions because a governmental agency gains or looses power as it is able to provide more or fewer services, more or less efficiently to more or fewer individuals and interest groups. That is, a governmental agency recruits the political support essential to maintaining its position vis à vis other governmental agencies by performing services for some segment of the public or other governmental agencies. The less service it provides, the less support it is likely to recruit and less influential in the general decision-making process of government it is likely to become. The transfer of many public services from general trial courts to labor arbitration panels, workmen's compensation commissions, domestic relations and juvenile tribunals, parole officers and boards and a host of other special mediational and decisional bodies is, at least from the point of view of political jurisprudence, a major shift in the structure of government and a reduction of the political power of courts and judges. Moreover, much of the study of these matters has proceeded on the basis of rather naive discussion about the "merits" of various bodies and the work-load of the courts. It is an old truism of public administration that shifts in organization and jurisdiction are never simply technical. They are almost invariably vehicles for policy change. The transfer of a particular service from one governmental agency to another inevitably alters the nature and direction of the service. Organizational change thus implies a shift in who gets what, the basic question of politics. Obviously the shift of decisional services from courts to other agencies must have the consequence of favoring some

(Footnote continued from preceding page)

recent study has concentrated on juries. See Broeder, The University of Chicago Jury Project, 38 Neb. L. R. 744 (1959); Bevan, Jury Behavior as a Function of the Prestige of the Foreman and the Nature of His Leadership, $7 \mathrm{~J}$. of Public Law 419 (1958). 
social interests over others-or more precisely favoring a different set of interests than the older arrangement did. This is obvious in the shift to labor arbitration boards, but just as true in the transfer of juveniles to special courts for special treatment. One of the tasks of political jurisprudence will be to analyse this essentially political problem in an essentially political way. While it has been presented here in the context of local government, the problem also exists at other levels and obviously is at the heart of such disputes as that over the scope of judicial review of administrative findings. Again this is basically a problem in intergovernmental relations and bureaucratic control. Just as we must assess the political relation between higher and lower appellate courts, we must fit the trial courts into the judicial policy-making process.

Aside from the general criticism that political jurisprudence overemphasizes the similarity between courts and other governmental agencies, it is likely to be urged that it considers courts and judges to the almost total exclusion of law. The central concern of jurisprudence is after all law, not simply judges. The import of this criticism will, of course, depend on whether you believe that there is something in law which can be discovered only outside of the men and institutions that make and apply it and to whom it is applied. In short, for the exponent of natural law, political jurisprudence is a very partial jurisprudence indeed but, as I hope to show presently, not an incompatible one. Accepting, arguendo, that political jurisprudence is a partial one, that is not enough to condemn it. Indeed, the absence of a single all encompassing theory and philosophy of law is the leading phenomenon of twentieth century jurisprudence and has been so much commented upon and so closely linked with the general fragmentation of contemporary political philosophy that nothing further need be said about it at this point. ${ }^{68}$ If political jurisprudence is not complete and all encompassing, it is in good company.

I believe, however, that a somewhat less modest case can be made for political jurisprudence. Legislation, that is, the passage of statutes by legislatures, had by the early twentieth century become the principal mode of law-making. Today it is rivaled

68 See the last section of this article. 
by administrative law-making. As long as Anglo-American law was largely common, i.e., judge enunciated, law and the judge were viewed as law discoverer or deducer, and Anglo-American jurisprudence could concentrate on an abstract examination of legal principles and how the judge did and should relate those principles to specific fact situations. Once the emphasis shifts to law-making, and to law-making by legislators and bureaucrats, such a jurisprudence becomes increasingly narrow and divorced from the realities of law. The crucial problem of modern American jurisprudence is to frame a legal theory and philosophy that somehow integrates statutory and administrative law with its more traditional concerns. ${ }^{69}$

Most scholars would agree, I think, that a jurisprudence based entirely on general examinations of the nature of law, divorced from analysis of how the law is made and applied and what it actually does, runs the danger of excessive formalism and eventually complete divorce from real law in the real world. As a result, study of the judicial process has always played an important part in jurisprudential endeavor. But today when the bulk of law is intimately connected with the legislative and administrative process, any jurisprudence which combines general discussion of law with examination of the judicial process alone is highly incomplete and distortive.

It is for these reasons that political jurisprudence provides an opening toward a more complete American jurisprudence. By emphasizing the inseparability of courts and judges from a political process that includes legislatures and bureaucracies, the new jurisprudence focuses attention on the need to incorporate the study of legislative and administrative law-making into legal theory. Political jurisprudence uses the tools of political science, tools originally designed for the analysis of legislatures and bureaucracies. Having incorporated the methodology of political science into jurisprudence for the purpose of studying courts, jurisprudence thus equipped will also be in a far better position to undertake the study of legislative and administrative lawjudiciary are inseparably tied to the politics of legislatures and administrative agencies will inevitably turn his sights on the

${ }^{60}$ See Hurst, The Growth of American Law: The Law Makers (1950); Auerbach, Garrison, Hurst and Mermin, op. cit. supra note 34. 
entire political and governmental matrix of law. Political jurisprudence will naturally expand from a political analysis of the judiciary to an analysis of the entire law-making process and its relation to traditional jurisprudential concerns. Today the focus of law and law-making is in what we used to call the "political branches." What better way to bring those branches into the jurisprudential fold than through a political jurisprudence?

Having made the most sweeping claims for political jurisprudence, admittedly on the basis of projected tendencies rather than solid results, and largely for the purpose of showing that even a partial jurisprudence may be useful in contributing to a broader one, it might be well to also make the most modest possible claims. There are many areas of law in which courts must either openly or covertly, consciously or unconsciously, formulate a political theory or establish some vision of the behaviour of their fellow political actors. For instance in dealing with contempt of Congress prosecutions, the federal courts must develop a whole theory of Congressional investigations. What are they and what should they be? What is the relation between the investigating committee and the House or Senate which authorized it? What procedures are appropriate to committee hearings in light of their functions and relation to their parent body? Examples could be multiplied endlessly. Quite obviously in the area of administrative law alone, there are hundreds of questions of law that depend upon notions of what agency behavior is and ought to be.

Unfortunately when one comes to look at these decisions, a great many of them seem to be based on incredibly naive or formalistic assumptions about the nature of American government and how it operates. At least in those areas where legal judgments must inevitably be based on political fact and evaluation, political jurisprudence could substitute some knowledge of what we actually know about politics and government for the making. The scholar who begins with the politics of the judiciary and its relation to law and then finds that the politics of the cliches of the civics text that we so often find in or slumbering behind legal discussions. ${ }^{70}$

70 See Horn, The Warren Court and the Discretionary Power of the Executive, 44 Minn. L. Rev. 639 (1960); Shapiro, Judicial Review: Political Reality and Legislative Purpose: The Supreme Court's Supervision of Congressional Investigations, 15 Vand. L. Rev. 535 (1962). 
The need for a more intimate relation between what we really know about government and the legal rules it formulates is probably clearest in the field of statutory interpretation. One of the most fruitful applications of political jurisprudence would be a full scale reexamination of the cannons of statutory interpretation and the uses of legislative history in the light of what we have learned in recent years about the actual workings of legislative bodies as opposed to their formal procedures. ${ }^{71}$ In this respect it must be admitted that many of the political superficialities to be found in legal discourse are actually consciously adopted legal fictions like the plain meaning rule which is an attempt to force the legislature to speak clearly not an assumption that it does. Admitting the usefulness of legal fictions, political jurisprudence might still indicate just where truth leaves off and fiction begins and which fictions are not purposeful tools but half-conscious assumptions about the nature of American government that have no basis in fact. A fiction, particularly a fiction about government, is useful precisely to the extent that we know it is a fiction. Beyond that point it may be more dangerous than useful. In any event political jurisprudence will, I hope, put a stop to studies like one I recently read-and one by a political scientist at thatwhich managed to discuss the Supreme Court and federalism for thirty pages without any reference to the substantial body of knowledge about how American federalism actually works that has been gathered by political science in the last thirty years. No matter how telling the criticisms of the institutional wing of political jurisprudence, it does provide us with much knowledge that is plainly applicable to the analysis of many legal doctrines.

While the institutional wing has been the object of some attacks, largely I believe because of sins of omission that can be remedied, it is the wing of political jurisprudence that concentrates on the attitudes and actions of individual judges which has taken most of the broadsides.

We have already noted the general distaste for statistical examination of judicial attitudes and voting. But in fact we all count and make at least rough quantitative assessments. What

71 See e.g., Bailey, Congress Makes A Law (1950); Gross, The Legislative Struggle (1953); Truman, The Congressional Party (1959); Mathews, U.S. Senators and Their World (1960); Wahlke, Eulau, Buchanan, Ferguson, The Legislative System: Explorations in Legislative Behavior (1962). 
practicing lawyer has not on occasion advised a client (predicted?) that a suit would be unsuccessful, not on the basis of the legal question but because his past experience indicated that such suits are usually lost. The experience he calls upon is simply unconscious quantification. The gossip of every county court house and the little internal moans or cheers that go up when the practicing lawyer finds out which of his cases are going to which judges, are simply unsystematic attitudinal conclusions based on quantitative observations over time. It would take a sternly disciplined student of constitutional law indeed not to mentally count up to at least five when he is asked nearly any question about the current meaning of the first amendment or the due process clause. We all count. Some of us use our fingers and some use statistics. Unless there is a special virtue in primitive or half-conscious methods of counting, I do not see the objection to statistics. As a matter of fact both simple counting and relatively sophisticated statistical analysis have been used by eminently respectable and lawyer-like figures. ${ }^{72}$ It is, therefore, probably not statistics alone but statistics used in conjunction with attitudinal and behavioral studies that are the main target.

There are to be sure some glaring weaknesses in the bulk of the attitudinal research that has been done so far, the most marked of which is its circularity. Observing that a certain judge always votes for the civil rights claimant, the attitudinal researcher says he has a "pro-civil rights attitude." Then at least by implication the "pro-civil rights attitude" is proposed as the cause of the pro-civil rights voting behavior. ${ }^{73}$ Thus the behavior under another name becomes its own explanation. At best this method is tautological.

There are also some difficulties with several of the principal methods employed in isolating attitudes. The general logic of Gutman scaling is not entirely clear. Its logic is further attenuated

72 Hart, The Time Chart of the Justices, 73 Harv. L. Rev. 84 (1959); Zeisel, Kalven and Bucholz, Delay in the Courts (1959). See the symposium on jurimetrics in 28 Law \& Contemp. Prob. (1963).

${ }^{73}$ I say at least by implication because even if the attitudinal researcher doesn't make the claim directly, he surely is not driven by idle curiosity to examine attitudes. He must be examining them in order to explain behavior. Similarly, where it is found that judges who are Republicans favor heavier sentences for criminals, it is assumed that favoring heavier sentences is an aspect of Republicanism and then it can be concluded that Republican judges who favor heavier sentencing do so because of their Republican attitudes. 
when scaling is transferred from the area for which it was intended into the analysis of judicial attitudes. The Gutman technique was designed for the examination of a random sample from a much larger universe. If the sample scaled, then the universe was presumed to be orderable along a single attitude dimension. But the scalograms of Supreme Court voting are not random samples. The cases used are pre-selected and are chosen precisely because the investigator hopes they reveal a single attitude dimension. The result is that it is never certain whether the Justices scale-that it can be arranged along a single attitudinal dimension like pro- to anti-business-or whether the cases scale, yielding the desired results because of the factors employed in their non-random selection.

Attempts to derive attitudes from observation of group voting behavior or alliances encounter similar difficulties. In the larger world it may be possible to safely assume that a number of people who consistently act in the same way and in conjunction with one another share an attitude. But where only nine persons are present and confined by an elaborate set of decisional rules that rigidly delimit their possible choices of action, it is not safe to infer that just because four or five Justices always vote together on certain issues, they have the same attitudes on those issues. Indeed bloc analysis has typically shown us a block of four and then five Justices who automatically become a bloc because they oppose those four although they seem to have nothing else in common.

All this is not to say, however, that the bullk of attitudinal research has been valueless. Quite the contrary. In the first place the data in social science can rarely be made to "prove" anything. Scalogram and group analysis are suggestive and provide important evidence even if they are not absolutely without scientific flaw. Few of us would be unwilling to accept the proposition that if a given judge always votes for the union, even when most of his colleagues find the law to point the other way, he probably is governed at least in part by pro-union sentiment. Secondly, the general problems of inference can be and have been reduced by careful extention and interpretation of the data. If a judge always votes pro-business in business regulation cases, he might do so for many reasons, legal or attitudinal. If he is also found to vote 
pro-business in business-labor disputes and tax cases, we surely make a fairly good case for pro-business attitudes. Thirdly, and this applies particularly to scalogram analysis, there is no reason to impute lack of intellectual honesty to researchers simply because their methods cannot guarantee absolute impartiality and exactitude in the scientific sense. So long as we can examine their case selection for ourselves and replicate their work, their findings need not be treated with particular suspicion. Moreover, some of the problems of lack of randomness in the selection of cases to be scaled can be solved by selecting all of the cases within a given subject area so that in effect one proves that the universe scales by scaling the whole universe. ${ }^{74}$

Perhaps the best answer to the weakness of much of the attitudinal research, particularly to its basic problem of circularity, is more and different attitudinal research. We would obviously be in a much better position to show the kind and degree of relation between judicial attitudes and judicial decisions if we were to establish the attitudes independently and then compare them with the judges' decisions, rather than finding that the attitudes derived from the opinions match the opinions from which they were derived. A start has been made in this direction by using direct questionaires to establish judicial attitudes. ${ }^{75}$ In the future both socio-economic analysis and survey research techniques, which are widely used in the social sciences, should be employed in the development of a body of independent data on the attitudes of judges. Moreover, the depth interviewing techniques recently used in the analysis of state legislatures and now of city councils could be used to gather such data and more especially data on the difference in attitude between judges and other politicians, particularly on the question of how each conceives his own political role. ${ }^{76}$

74 This technique has frequently been used in the literature cited earlier although the problem remains as to whether the universe chosen, all the labor cases for instance, is a universe within the logic of the Gutman method or simply a large but non-random sample. Often in statistical work increasing the number of cases decreases the possibility of distortion. But since the number of Justices remains constant at nine, increasing the number of cases actually seems to increase the chances that the cases rather than the Justices happen to scale. (I am indebted for this latter point to John Sprague, a $\mathrm{Ph} . \mathrm{D}$. candidate at Stanford). 1963).

75 Nagel, Off-the-Bench Attitudes, Judicial Decision Making (Schubert ed.

76 See Wahlke, Eulau, Buchanan, Ferguson, op. cit. supra note 71. Professor Eulau is currently engaged in the application of similar techniques to the study of city councils. 
However, since attitudinal research up to this point has been more suggestive than conclusive, there has been some outcry that the results have not been worth the effort, that statistical approaches have only tended to confirm what we knew already. This argument is really part of the general debate between behaviorists and non-behaviorists in which the behaviorists are accused of employing fancy methodologies to prove the commonplace. But it can hardly be possible that all our truisms and cliches are correct since many tend to contradict one another. Systematic analysis designed to test traditional knowledge cannot, therefore, be wasted even when it tends only to confirm some of our previous impressionistic notions.

Nevertheless, the problem of lack of originality seems particularly acute in the attitudinal area of political jurisprudence. It has been further aggrevated by the kind of overenthusiastic claims about returning the study of law from its dark corner to the mainstream of intellectual endeavor, systematizing a previously anachronistic discipline and replacing a collection of cliches with a new science that are to be expected in a new intellectual movement but nevertheless bring a pang of regret that adolescence must proceed maturity. Novel methods are not to be confused with new results. And unfortunately most of the old cliches that the new attitudinalists have been able to puncture are cliches that no well informed traditionalist currently believes or over which there had already been considerable disagreement based on conventional analysis, disagreement that statistical findings somewhat sharpened but did not end. After a thorough review of the new literature, I cannot honestly say that it has so far made any startling new contribution to our knowledge of courts and judges. Its value has largely been in presenting further evidence for certain already well formulated hypotheses. Again, however, it must be insisted that this is not a negligible accomplishment.

An important factor in this concern over originality is that attitudinal and small group analysis has so far been largely concentrated on the Supreme Court. The level of traditional scholarship is so high in this area, the examination, reexamination and comparison of data even by traditional and allegedly cumbersome means so thorough, that no new method, statistical or otherwise, 
is likely to bring more than a small increment to what we already know. ${ }^{77}$ The claimed economies and capacities for original insight of statistical analysis in general and more particularly of attitudinal research will be given a better test as political jurisprudence shifts its major emphasis away from the Supreme Court about which in a sense we know too much. The new methods seem best suited to the study of lower courts which have been relatively neglected by traditional analysis and seem peculiarly suited for statistical and sociological treatment because of the huge amounts of data to be correlated and interpreted.

\section{On the Inseparability of Traditional and New Analytical Techniques ${ }^{78}$}

Skimming through the recent writings of Schubert, Ulmer, et al, the casual reader, depending upon his prejudices, might conclude either that the new research represented a formalastic game totally divorced from the real substance of law or a simple and blessed release from the stylized and highly complex maneuverings of traditional case analysis. The result is likely to be a debate over whether the new techniques can independently do the job that traditional analysis had formerly done and do it better. Such a polemic should in general be avoided, for to my knowledge no political jurist has ever claimed that the new methods were either totally independent or sufficient means of examining the work of courts. It is true, however, that for the most part the users of new techniques have contented themselves with the academic courtesy of conceeding the legitimacy of other scholarly work rather than systematically explicating the dependence of their own findings on traditional analysis. It might be well then to indicate something of the inter-dependence of new and traditional methods both to disabuse the "outsider" of the notion that an important wing of political jurisprudence is no more than wild-eyed scientism and to show the acolyte that he is not relieved of the duty of learning the traditional services.

77 It might be added in passing that before we accuse the attitudinalists of wasting time elaborately proving cliches, we might consider whether the hundreds of thousands of often routine or formalistic words written about the Supreme Court and its opinions every year really represent the best allocation of scholarly resources.

78 By "traditional" I mean the analysis in depth of the facts, law and reasoning of judicial opinions according to the dialectical conventions that lawyers and judges normally employ. 
The scalogram has surely been the most prominent of the new tools. Yet as we have seen the cases used in each scalogram have not been the result of random sampling. They are carefully selected and in most instances the inclusion or exclusion of a given case, particularly of ambiguous or multi-issue cases, has been supported by traditional analysis going to the substantive legal issues. On the whole the case groupings have been just those that any traditionalist would have chosen and have been openly dependent on traditional analysis. Whether or not to establish sub-scales or engage in multiple counting ${ }^{79}$ and what cases are to go into what sub-scale are questions that are also largely dependent on examination of the substantive content of the decisions.

Where a scale appears to meet statistical requirements of reliability but is imperfect in the sense that some of the votes of certain Justices are inconsistent with their general scale position, these inconsistencies may be explained by peculiar factors that become evident when the Justices' opinions are subjected to traditional analysis. Where cases that logically fit into the group of cases to be scaled are in fact inconsistent or disruptive of the scale patterns, these inconsistencies may be explainable by turning to the legal issues in the case and the opinions of the Justices. Again all this is not meant to imply that the scales have unconsciously or obscurely smuggled in outside conclusions based on other techniques. The employment of traditional techniques and conclusions has been open and purposeful.

Bloc, factor and game theory analysis are also closely tied to traditional techniques. It is generally impossible to say that the discovery of a bloc of four or five appellate judges constitutes more than a purely formal statement of congruent behavior unless the statistical presence of the bloc is supported by analysis of the members' opinions to discover whether they express or acknowledge attitudinal agreement. The necessity of forming judicial as well as legislative majorities may often make strange and antagonistic bed-fellows. A pioneering attempt at applying factor analysis to Supreme Court behavior was able to derive acceptable vectors and intensities but the initiators of the study

70 See Spaeth, Judicial Power As a Variable Motivating Supreme Court Behavior, 6 Midwest J. of Politics 54 (1962), for the use of sub-sclaes and Tannenhaus, supra note 49 , for double counting. 
concluded that only subject matter specialists could give substantive labels to their formal descriptive statements. ${ }^{80}$ While some game theory analysis may proceed purely on the basis of voting behavior, most will require fairly elaborate traditional analysis since the judicial game requires that the players govern their strategies in part by legalistic conventions. If for no other reason, this is true because certain of the players may place a high premium on legal reasoning and other traditional concerns. ${ }^{81}$

Finally, attitudinal-statistical approaches can be used most independently in those situations in which differences in judicial behavior are most clearly explainable in terms of differences in broad social attitudes like pro- or anti-business sentiment. If all the judges decided all the cases on the basis of a few fixed attitudes, we could all afford to sit back on our Gutmans. But even the analyses of the Supreme Court done up to this time shows clearly that things are not so simple. Scale analyses for reasons sufficient unto the method have usually omitted unanimous decisions. Nevertheless such decisions make up a significant part of the whole, are probably the least dependent on attitudinal differences and the most related to conventional legal thinking of all varieties of decision and, therefore, are likely to remain heavily dependent on traditional and rather complex legal reasoning for explication.

More important, both bloc and scale analysis show a middle category of Justices. Assuming for the moment that a near perfect scale does show that the Justices are ordered according to a single attitude, the scales also typically show a set of intermediate Justices falling between those who always vote for and those who always vote against a certain social issue or policy. Their position on the scale indicates that they hold the scaled attitude less strongly or less extremely than those of their colleagues at the two ends of the scale. ${ }^{82}$ Since these Justices vote no in some of

80 Thurstone and Degan, A Factorial Study of the Supreme Court, Proceedings of the National Academy of Sciences 628 (1951). Schubert has attempted to avoid traditional analysis by using scalogram analysis to formulate suitable labels. Schubert, A Solution to the Indeterminate Factorial Resolution of Thurstone and Degan's Study of the Supreme Court, 7 Behavioral Science 448 (1962). But this only transports the traditional analysis one stage backward to the construction of the scales.

81 See Schubert, supra note 33.

82 But unless their votes violate the scale orderings, their intermediate position does not show that they are inconsistent in their attitudes. In terms of Gutman

(Continued on next page) 
the categorized cases and yes in others, while their colleagues with more strongly held attitudes tend to vote consistently yes or no, it is precisely this intermediate category of Justice whose votes frequently decide the Court. Thus scale and bloc analysis paradoxically tend to show that the decisions of the Court as opposed to the decisions of individual Justices are made on the basis of relatively weak attitudinal differences and thus are least amenable to these techniques. It is precisely those Justices whose votes are most decisive in the disposition of cases whose behavior can least readily and neatly be explained by proposing a direct, unadulterated relation between their social attitudes and their legal decisions. And because of the basic circularity of most attitudinal research, we cannot actually tell whether these intermediate Justices vote the way they do because of relatively weak social attitudes or in spite of relatively strong ones.

It is the unanimous cases and those decided by the votes of the intermediate Justices that are most likely to exhibit decisions based on something more complex than simple social attitudes. Since these constitute a major share of the Court's business, it is likely that traditional analysis will continue to play a larger part than the new techniques in the analysis of the Court's relations with other political agencies. ${ }^{83}$

Attitudinal-statistical techniques are also highly dependent on traditional analysis as a check on their conclusions. Their whole basis is that an observed uniformity of behavior must indicate a single attitudinal factor at play, but for any attitude other than the attitude of following the law, this would be true only if the data were random in the sense that the legalities of the cases

(Footnote continued from preceding page)

scaling any judge is consistent who has a distinct break between his yes $(t)$ and his no $(-)$ votes with no pluses in amongst his minuses and no minuses in amongst his pluses.

83 It should be added that the long presense of two such justices as Black and Douglas is something of an historical accident and encourages the kind of simple social attitude analysis that seems to suddenly take all the complexities out of public law. Ulmer struck at this oversimplification in group analysis some time ago. See his Polar Classification of Supreme Court Justices, 12 S.C.L.Q. 407 $(1960)$. One of Schubert's most recent pieces, Civilian Control and Stare Decisis in the Warren Court, Judicial Decision Making (Schubert ed. 1963), stresses the complex and varying motivation of the Justices. These pieces, together with those cited at note 84 infra, indicate an increasing tendency toward subtlized and complex analysis and, of course, the more complex attitudinal-statistical analysis becomes the less attractive it becomes as a substitute for traditional analysis since it looses its initially promised capability of quickly cutting through a mass of traditional obfuscations to the simple truth. 
randomly favored first the business and then the anti-business litigant. If a single decisional rule, i.e., a "legal" or "technical" rule, or a series of decisional rules when applied to the selected cases would yield the observed uniformity, then the cases are not random and the uniformity is not conclusive for either the identification of attitudes nor the supposition that the identified attitude was the cause of the observed uniformity. The more initially structured the cases, the less reliance for inferences about attitudes may be placed in observed uniformity of decision. More particularly, statistical standards of reliability established in areas where data is highly random or can be randomized are not necessarily applicable in areas where data is highly structured.

The work of courts tends to be highly structured for several reasons. First of all, a statute, either by design of the legislature or simply because it is a single set of words with a relatively clear meaning on its face, constantly applied to similar fact situations may consistently favor one interest in the community over others -indeed statutes do and are designed to do just this. Therefore, in the area of litigation covered by a given statute, the legalities are not likely to randomly favor one interest and then another.

Admittedly appellate courts tend to get those cases where the legalities are not absolutely clear. It is this tendency toward randomness that makes attitudinal-statistical studies even passingly plausible. But most cases do clearly arise under a single statute. Typically cases under a given statute tend to keep coming to appellate courts because two alternative interpretations continue to be held by different judges or litigants. But once a single appellate judge has determined that interpretation $X$ is correct, he is likely to consistently interpret the statute as meaning $X$ even though other legal authorities believe it to mean $Y$. Furthermore it is not outside the realm of probabilities that he chooses interpretation $X$ not because it suits his attitudes about what interest should be favored but because he believes that the legislature really intended or the plain meaning of the statutory language really requires interpretation $X$ although some of his colleagues disagree. Indeed he may feel that the reason why the case comes up on appeal is that the legislators really intended $X$ and those people-including judges-who wish they had intended $Y$ keep trying to read $Y$ into the statute. Thus a judge who decides 
cases under a statute that he feels favors business may issue consistently pro-business opinions because he desires to enforce the statute not because he has a pro-business attitude or allows his economic attitudes to dominate his legal views.

Attitudinal-statistical approaches may attempt to overcome this phenomenon by drawing their categories broadly so that cases arising under two or more statutes are thrown together. Any uniformity that is observed then cannot be ascribed entirely to the phenomenon described above. But admitting that legislatures are not entirely consistent in always choosing one interest over another and are not notorious for highly coordinated legislative programs, it is probable that two or more statutes which are closely enough related to be lumped together for attitudinal research may very well have been inspired by similar legislative choices as to which interest should be favored. It is not inconceivable that two statutes both of which will involve businessmen as litigants are both clearly intended by the legislature to favor business interests so that consistently pro-business decisions under both statutes may still establish only a judge's desire to follow Congressional intent not a pro-business attitude. Of course, the more statutes are lumped in a given category the less liklihood there is of consistent legislative intent. Nevertheless, it is probable that many interlocking series of statutes are intended, either consciously or as a result of the long dominant position of a given political coalition in the legislature, to consistently favor certain interests over others.

The materials of judicial decision are further structured by the phenomenon of litigation as a form of political activity. Interest groups frequently undertake campaigns of litigation aimed at getting the courts to change the existing state of either the case or decisional law. Or they may resort to the courts precisely because they find that the current state of the law in the courts favors them more than the current state of other political arenas. Opinions consistently favoring a given group may not mean that the judge is shaping the law to favor the group, but that the group has found that the existing law favored them and resorted to the courts precisely for this reason. Thus the cases that come before the courts may not be random on their legalities but preselected by litigating groups. 
Administrative and regulatory agencies frequently find that, due to changes in economic or social conditions, a statute whose intent has long been acknowledged, or a line of decisions that is clear and consistent, is now yielding undesirable results, i.e., results that favor social interests that the agency does not favor. Such agencies may persistently litigate cases with the hope of getting judicial amendments. For instance, the National Transportation Policy was framed in the 1930's when trucking was an infant industry and, therefore, it provided special aids to truckers vis à vis railroads. The ICC, applying the act in the 1960 's, may repeatedly attempt to shift its thrust to end a favoritism that seems unwarranted in today's changed circumstances. The agency may try to accomplish this goal by petitioning Congress to amend the act or alternatively by issuing a set of pro-railroad, anti-truck rulings in marginal cases. In the subsequent litigation, the commission seeks to gradually nudge the Supreme Court into accepting its views and thus amend the statute without legislative action. Is a judge who consistently resists the prod of the ICC exhibiting an anti-regulatory agency or pro-railroad attitude, or is he simply attempting to obey Congressional commands however outdated and incorrect they may be?

Again this problem can be overcome by extending the range of cases considered to cover more than the truck certification business of the ICC or more than one regulatory agency. But it is also likely that there are institutional pressures that cause all the regulatory agencies to push against outdate commands of Congress so that a consistent anti-regulatory agency position might evidence not a pro-business, anti-regulation attitude but a pro-Congress anti-amendment-without-statute attitude. In other words, the cases may be read Regulatory Agency v. Business but be decided Regulatory Agency v. Congress.

The pool of litigation is thus not a random one but is often marked by litigational campaigns that may bring similar parties under similar legal rubrics to an appellate court over and over again. Uniformity of decision may, therefore, indicate either an attitude favoring a given variety of party or an attempt to maintain a consistent position toward the legal rubric.

Finally, correspondence of litigating party with legal rule litigated may lead to consistencies that seem ordered on the basis 
of social attitudes but in fact reflect some other structuring of the materials. This is perhaps only a variation of what I have just written. Even without conscious litigational campaigns, certain kinds of people will consistently invoke the protection of certain constitutional provisions, statutes or previous court decisions. It is the poor who usually invoke the right to counsel clause, labor unions that invoke certain of the unfair labor practices provisions of the National Labor Relations Act, Negroes who invoke Brown v. Board. A judge who has no markedly pro-Negro attitude might nevertheless consistently vote for Negroes if all the cases that reached his court involving Negroes were educational desegregation cases. A judge who had no particular love of labor unions might compile a wonderfully pro-union record if all the labor cases involved prohibited, employer, anti-union practices. Of course all the cases involving Negroes are not desegregation cases and all the cases involving unions are not employer practices cases. But there is a sufficient level of correspondence between party and legal rule that a given line of decisions by a given judge may sometimes indicate commitment to a given interpretation of the rule rather than an attitude toward the parties. It is true that commitment to a given interpretation of the rule may itself be initially the result of an attitude toward the parties, but unless one entirely rejects legal training and logic as operative forces in the judicial mind, such commitment might alternatively be the result of rational-legal calculation based on the perhaps incorrect notion that laws do have an objective meaning whether we like it or not.

I am not suggesting that all of these factors are always operating or even that any one of them is always operating suffleiently to render attitudinal-statistical analysis inoperative. However, in every instance where statistical methods are employed, traditional analysis will be necessary to isolate and assess these factors and determine to what extent they undercut the statistical propositions. In some instances such analysis may result in discarding the statistical propositions. In others, it will be used to indicate that no undermining factors can be discovered. In a great many instances of course, the result will be something between full abandonment or acceptance of the initial attitudinal analysis. 
A word further must be said about the statistical extension and manipulation of categories to avoid or at least mitigate the three problems of non-randomness sketched here. Broadening categories is not an automatic or complete solution. Let us say we are attempting to establish a pro-civil liberties attitude. We begin with freedom of speech and show that judge $X$ consistently disfavors speech claims. When we are told that this may be because all the speech cases in question involve state action and thus issues of federalism, we add no-establishment of religion cases and show that he disfavors all such claims. In reply we are told that he may do so not because he is anti-civil rights but because he is convinced by historical research that the no-establishment clause was not intended by the framers to create a wall of separation. As we add areas, we may be greeted each time by a new decision rule based on legislative intent, stare decisis, judicial modesty, reasoning from neutral principles etc, which explains the judges behavior on grounds totally divorced from civil rights attitudes. When we find that the sum total of all these decisional rules just happens to be a consistently anti-civil rights position, we may be suspicious, but our respondent may be right. There will rarely be enough categories available for introduction to statistically prove that it is an anti-civil rights attitude that motivates the decisional pattern and not a series of inter-related or even independent decisional rules which coincidently yield consistent anti-civil rights results. It is not beyond the realm of belief and certainly not beyond the realm of statistical possibility that four or five firmly held legal doctrines largely divorced from any single social attitude may in thirty or forty cases yield a pattern that falsely suggests such an attitude.

The same kind of problem exists when analysis proceeds by reduction. Let us suppose that we suggest that Justice $X$ is antibusiness and our respondent replies that most of the decisions on which we base our conclusions are regulatory cases and in fact what they show is that the Justice defers to administrative expertise. We then reply that Justice $X$ has upheld seventy per cent of the regulatory commission decisions unfavorable to the regulated firms but only fourteen per cent of those favorable to them. Our respondent replies yes, but your eighty-six per cent of favorable agency findings rejected by Justice $X$ are all cases in 
which the administrative agency went beyond its expertise and attempted to in effect amend the statute without Congressional consent. Again we may be suspicious, but we are unlikely to be dealing with numbers large enough or a universe sufficiently suitable to "prove" our case statistically. Probably our best bet at this point would be to return to traditional legal analysis in order to discover whether the cases in which favorable agency findings were rejected are really distinguishable from the others and consistent with the position toward agencies taken by the Justice in the opinions initially labeled anti-business.

Finally, those committed to attitudinal approaches are attempting to avoid many of the problems I have suggested by including "legalistic" attitudes among those to be studied. ${ }^{84}$ But this returns us directly to traditional legal analysis as an integral part of constructing categories for statistical use. The nice thing about pro and anti-business or civil rights or economic liberalism labels was that attitude categories could be constructed without case analysis simply by looking to the nature of the parties who had won and lost in the best "bad man's law" tradition. The work of Grossman and Spaeth suggests that when we begin dealing with judicial attitudes about law and the judicial process instead of about U.S. Steel and the AFL-CIO, we can only frame categories of cases that will isolate such factors, save for a few areas that are purely jurisdictional, by traditional analysis of the cases. There is no other way to divine which cases struck which of the Justices as raising procedural, role of the Court, or interpretory problems just as or more important than the nature of the two parties. $^{85}$

84 Spaeth, supra note 79. Grossman, Role Playing and the Analysis of Judicial Behavior: The Case of Mr. Justice Frankfurter, 11 J. Pub. L. 285 (1962).

85 Grossman's criterion for choosing cases to scale for his research is "questions of jurisdiction, federalism, deference to some other governing unit within the system or any question involving the right or propriety of the Supreme Court deciding the case ... [where] . . the issue of judicial responsibility was raised." Grossman supra note 84 , at 298 . Spaeth uses three criteria. 1 . Where the fact situation, issues requiring resolution and the points emphasized in the opinions clearly indicate the dominance of considerations of Supreme Court power as the basis for the Court's decision. 2. Those cases that did not scale on certain social attitudes (civil rights, business, labor, etc.) indices. 3. Comity and Federal Rules of Civil Procedure cases. Spaeth, supra note 79, at 56-57. Obviously a considerable amount of traditional analysis is necessary in order to employ these criteria. Note that Spaeth's second category indicates the progressive introduction of more and more levels of analysis when the simplest categories do not provide a complete explanation. See also Spaeth, An Approach to the Study of Attitudinal Differences As an Aspect of Judicial Behavior, 5 Midwestern J. of Political Science 165 (1961). 
Moreover such attitudes are much more difficult to isolate and express in the yes-no or plus-minus language of statistics than hypothesized attitudes toward the parties and tend to return the study of judicial motivation to the rather murky mixture of legal reasoning and social judgments from which the simple format and glorious white space of scalograms sometimes seems to be rescuing it.

In summary then, traditional analysis plays an important role in establishing the categories and format of the new forms of analysis, is required for support and interpretation of the findings of such analysis and is frequently a convenient proof or check on both its methods and conclusions. In this connection it should be added that some of the political jurists have been guilty of a considerable number of errors or overstatements and their conclusions have been subject to a number of specific criticisms that could have been avoided or anticipated by more thorough traditional analysis and exposition. ${ }^{86}$ These errors are doubly unfortunate because they are often seized upon to discredit the new methods when in fact they are simply evidence that few of us are perfect in our scholarship, traditional or otherwise. ${ }^{87}$

Traditional, statistical and behavioral techniques are now inextricably mixed in political jurisprudence and will undoubtedly remain so. Not all political jurists need use all of them nor need we waste time trying to determine an orthodox "mix." Either in the mind of a single scholar or the complementary work of several, most problems in political jurisprudence will require a variety of approaches in order to build up a cumulative solution.

\section{The Perennial Question-Is and Ought}

Critical students of jurisprudence who have bothered to follow me this far are likely by now to have two dread words, naive and positivism, ready at hand. It must be confessed that either out of naivete, or because many of its participants see

86 Cramton and Zeisel, Review of Schubert, Quantitative Analysis of Supreme Court Opinions, 28 U. Chi. L. Rev. 174 (1960); Mendelson, The Neo-Behavioral Approach to the Judicial Process: A Critique, 57 Am. Pol. Sci. Rev. 593 (1963).

87 It would be possible to construct a considerable catalogue of errors, overstatements and incompletely supported conclusions in the new work. But errors should be pointed out and corrections made in the course of careful reinvestigation of particular problems not by polemic sharp shooting. Traditional analysis will undoubtedly play a considerable role in this process. 
themselves primarily as political scientists not students of law, political jurisprudence so far has failed to provide itself a theoretical rationale that grapples with the problems of twentieth century legal philosophy. This is a serious flaw in a movement that is so heavily dependent on sociological jurisprudence and legal realism both because there have been serious theoretical differences between the two and because each has been challenged by a revived idealism. However, I do not think this flaw is a fatal one because neither the conflict between sociological jurisprudence and realism nor the debate between positivism and idealism have yet been resolved. For the moment at least political jurisprudence can attach itself to the realist and positivist causes and refer its attackers to a set of arguments hallowed by extended if not particularly fruitful development. ${ }^{88}$ Nevertheless the strength of the revival of various forms of natural law jurisprudence requires some comment on the particular relation of political jurisprudence to the normative or valuational aspects of legal philosophy.

Political jurisprudence is basically positivistic in the sense of seeking to describe the political-legal processes as it is rather than prescribing how it ought to be. But if political jurisprudence is positivism, it is a peculiarly value-laden kind of positivism. The whole attitudinal wing is, of course, attempting to discover what values the participants in law-making hold and how these values affect their law-making activity. The essentially political inquiry into what governmental tasks the courts do efficiently and what services they fail to perform satisfactorily includes a determination of how well the courts function as creators and appliers of moral standards. ${ }^{89}$ The general emphasis of political

88 The positivism v. idealism rubric is, of course, rather bad shorthand since it uses the labels that each side pins on its opponents. Yntema, American Legal Realism in Retrospect, 14 Vand. L. Rev. 317 (1960), provides a concise outline of the former debate and Weissman, An Antitrust Law, Too, Must Be Just, 1962 Wis. L. Rev. 403, of the latter. The parallel debate in political science can be followed in Book Review Essay, 57 Am. Pol. Sci. Rev. 125 (1963). The close relation between realism and political jurisprudence can be seen in Llewellyn, Law and the Social Sciences-Especially Sociology, 62 Harv. L. Rev. 1286 (1949). Llewelyn's partial withdrawal from realism in Deciding Appeals, the Common Law Tradition (1962), has been attacked from the standpoint of political jurisprudence. See Clark and Trubek, The Creative Role of the Judge; Restraint and Freedom in the Common Law Tradition, 71 Yale L.J. 255 (1961).

80 See Shapiro, Morals and the Courts: The Reluctant Crusaders, 45 Minn. L. Rev. 897 (1961). 
jurisprudence on judge as policy-maker inevitably has made the demand that judges articulate their values and social goals an integral part of political jurisprudence. ${ }^{00}$ For policy-making is by its very nature purposive activity implying a choice between alternative means and ends based on some notion of the goods. The judge as policy-maker must, therefore, make moral choices.

I am well aware that many scholars view the reduction of values to psychological data, which then become part of the "is," as the final positivistic rape of moral philosophy. Similarly the emphasis on purposive elements in law-making may be viewed as a false reduction of law to will and appetite ignoring elements of reason and justice. Finally a jurisprudence which claims that the ought is an essential part of law, while at the same time devoting itself entirely to the is, may well be accused of either insincerity or misdirection. In the face of these arguments, it is not entirely satisfactory to say that political jurisprudence, by emphasizing the political and, therefore, valuation or purposive nature of law, provides a gateway for the passage from empirical to normative study. A gateway is not enough. Some one must go through it and tell us what is beyond.

But if political jurisprudence in the end shows itself incomplete, it at least points to the reasons for its own incompleteness and, indeed, for the unresolved quality of all modern jurisprudence. Since law and law-making are an integral part of politics, legal philosophy is an integral part of political philosophy. The problem of those who wish to create a value oriented rather than descriptive jurisprudence is that, apart from the NeoScholastics, they have been unable to formulate a coherent and generally acceptable statement of the values around which a new jurisprudence could be built. Indeed since the admittedly subphilosophical jural postulates of Roscoe Pound, nearly all the talk has been of the need for and means of finding moral principles rather than the substance of those principles. $^{91}$ The reason for

90 See Miller and Howell, The Myth of Neutrality in Constitutional Adjudication, 27 U. Chi. L. Rev. 661 (1960); Miller, A Note on Supreme Court Decisions, $10 \mathrm{~J}$. Pub. L. 139 (1961). Professors Lasswell and McDougal have long called for the systematic enunciation of values in law. For the close connection between their call for valuation and a view of courts as political agencies see Lasswell, The Interplay of Economic, Political and Social Criteria in Legal Policy, 14 Vand. L. Rev. 451 (1961). (1959).

91 See e.g., Northrop, The Complexities of Legal and Ethical Experience 
this failure is quite obviously the failure of post-Marxian political philosophy to provide any acceptable "truths" about the nature and ends of the government, ${ }^{22}$ and more particularly the failure of liberal-democratic philosophy, busy defending its threatened procedural axioms, to come to grips with the substantive issues that lie behind the phrase "public interest." in fact can appear so self-satisfied and complete only because they deal with law with a capital (or natural) L, or point out the contradictions of other political philosophers, rather than attempting the real and much more difficult task of integrating scholastic theories of law into modern Catholic political philosophy, a philosophy that has yet to prove itself congruent with modern industrial society.

Until political philosophy revives sufficiently to provide us with a set of ultimate truths or a reasonable facsimile thereof, jurisprudence is likely to concern itself with more immediate questions. There is a whole range of intermediate ought problems that we must solve now even though our ultimates are shaky. Ought property owners be forced to sell to Negroes? Ought competetive sectors of the economy be allowed to become oligopolistic? Ought the jurisdiction of juvenile courts be extended? If political jurisprudence provides us with some information on the functions of law-makers in our society, and in the process prods those law-makers into conscious political evaluation of their own governmental roles and the role of government in general, it will have contributed as much and perhaps more to the valuational aspects of jurisprudence as its contemporaries. 


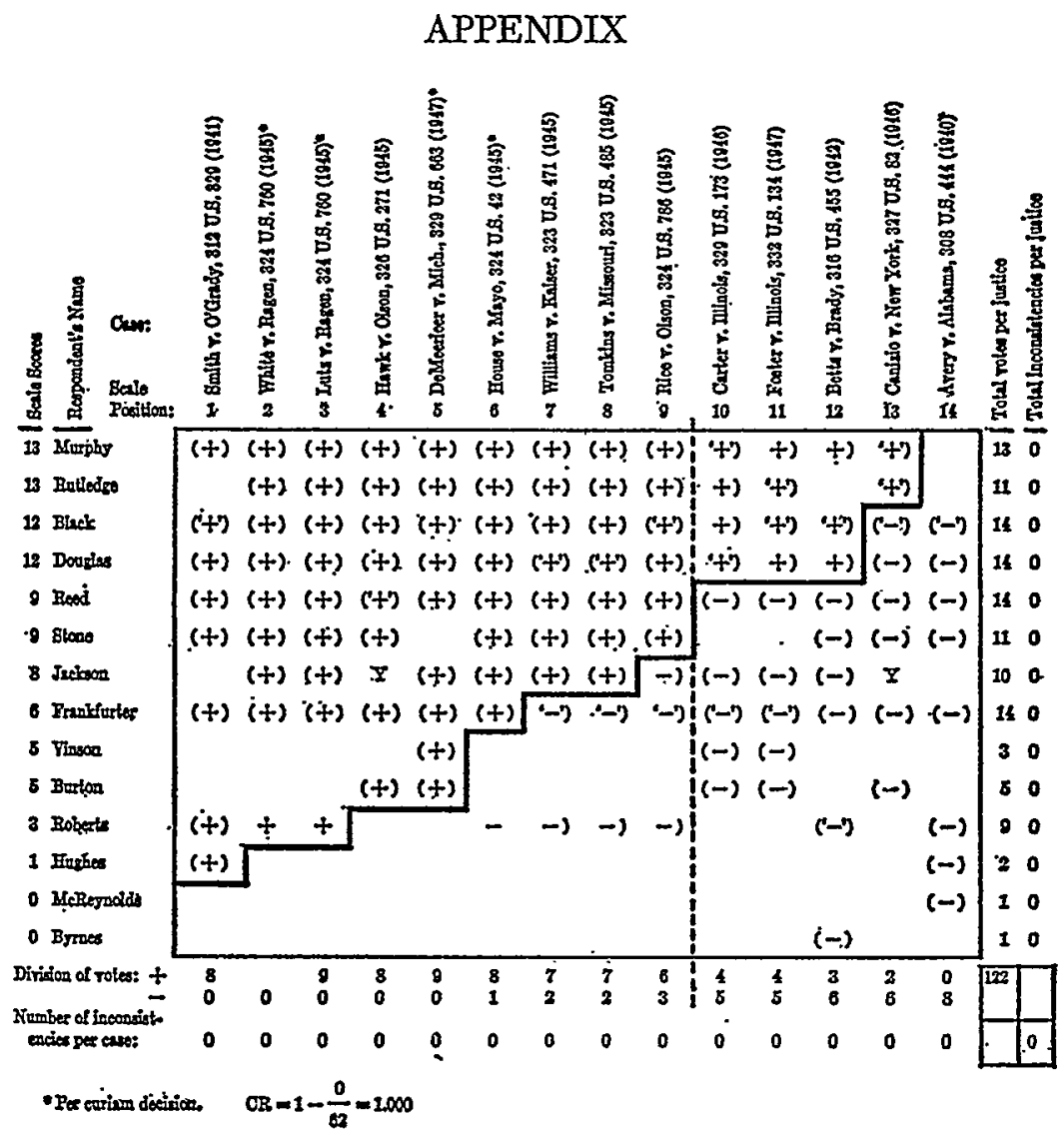

[Reproduction of Fig. 6 from Schubert, The Study of Judicial Decision Making, 52 Am. Pol. Sci. Rev. 1015 (1958).]

This is a perfect scale. An inconsistency would occur if Justice Douglas, for instance, had voted against the accused in House $v$. Mayo or Justice Frankfurter for the accused in Foster v. Illinois. In this scale eleven or more such inconsistencies would normally lead to the conclusion that the data did not actually scale, i.e., was not orderable to show a single attitude. 


\begin{tabular}{|c|c|c|c|c|c|c|c|c|c|c|}
\hline & 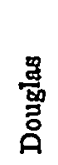 & 总 & 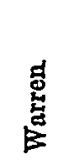 & $\begin{array}{l}\text { 莒 } \\
\text { 总 }\end{array}$ & $\begin{array}{l}\text { 总 } \\
\text { 葛 }\end{array}$ & $\begin{array}{l}\overrightarrow{\mathrm{g}} \\
\text { 出 }\end{array}$ & 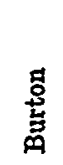 & 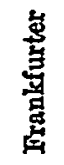 & $\begin{array}{l}\text { 营 } \\
\text { 㺃 }\end{array}$ & \\
\hline Douglas & & 80 & 67 & 50 & 34 & 30 & 31 & 34 & 30 & \\
\hline Blsck & 80 & & 77 & 58 & 44 & 37 & 36 & 46 & 31 & \\
\hline Warren & 67 & 77 & & (76) & $54^{\circ}$ & 55 & 53 & 55 & .42 & INDEX OS \\
\hline Clark & 50 & 58 & (76) & & $\overline{6} \overline{4}$ & 68 & $-6 \overline{3}$ & 55 & 46 & INTERAGREDMENT \\
\hline Minton & 34 & 44 & 54 & 64 & & 74 & $61 i$ & 54 & 49 & $I\left[L_{\text {eft }}\right]=.747$ \\
\hline Reed & 30 & 37 & 55 & 68 & 74 & & $71 i$ & 48 & $\mathbf{5 1}$ & $I I[$ Center $]=.673$ \\
\hline Burton & 31 & 36 & 53 & 65 & 61 & 71 & & $\overline{61}$ & 65 & IIRight $]=: 687$ \\
\hline Frankfurter & 34 & 46 & 55 & 55 & 54 & 48 & 61 & & $80 i$ & $I I(W a-C)=.760$ \\
\hline Firisn & 30 & 31 & 42 & 46 & 49 & 51 & 65 & 80 & & \\
\hline$\%$ of assent: & 70 & 78 & 88 & 89 & 81 & 80 & 79 & 80 & 71 & \\
\hline
\end{tabular}

[Reproduction of Fig. 2 from Schubert, The Study of Judicial Decision Making, 52 Am. Pol. Sci. Rev. 1011 (1958).]

The numbers represent the total number of paired votes in the selected cases. Thus Black voted in agreement with Douglas in eighty of the selected cases but with Harlan in only thirty-one. Clark is identified in this diagram as a "swing" Justice. 